Aspirasi: Jurnal Masalah-Masalah Sosial | Volume 9, No. 1 Juni 2018

ISSN: 2086-6305 (print) ISSN: 2614-5863 (electronic)

DOI: https://doi.org/10.22212/aspirasi.v7il.1084

link online: http://jurnal.dpr.go.id/index.php/aspirasi/index

\title{
PENGARUH KUALITAS LINGKUNGAN TERHADAP PEMENUHAN KEBUTUHAN DASAR DI PROVINSI BANTEN
}

\author{
Effect of Environmental Quality to Fulfillment of Basic Needs \\ in Banten Province
}

\author{
Anih Sri Suryani \\ anih.suryani@dpr.go.id \\ Pusat Penelitian Badan Keahlian DPR RI \\ Jl. Gatot Subroto Senayan Jakarta
}

Naskah Diterima: 14 Februari 2017 | Naskah direvisi: 20 April 2018 | Naskah diterbitkan: 30 Juni 2018

\begin{abstract}
To date, the quality of the environment and basic needs of the community is a matter of concern and need to be improved. This study aims to measure the effect of environmental quality on the fulfillment of basic needs. Mixed methods of quantitative (with questionnaires) and qualitative (by interview) are conducted in data collection and analysis. The results showed that all environmental quality indexes were correlated with the fulfillment of basic needs, except for the biodiversity index. Based on the correlation test it is found that all environmental quality index have positive effect on the fulfillment of basic needs. This means, if there is an increase in air quality, water quality, land cover, biodiversity, public health, and environmental health then the fulfillment of basic needs will increase, and vice versa. The air quality index and land cover have the largest constants among the other indices. Thus, an increase of those values will have a greater impact on the increase in basic compliance, and vice versa
\end{abstract}

Keywords: environmental quality, environmental health, basic needs

\begin{abstract}
Abstrak: Kualitas lingkungan dan kebutuhan dasar masyarakat selama ini merupakan hal yang menjadi perhatian dan perlu terus ditingkatkan. Penelitian ini bertujuan untuk mengukur pengaruh kualitas lingkungan terhadap pemenuhan kebutuhan dasar. Metode gabungan kuantitatif (dengan penyebaran kuesioner) dan kualitatif (dengan wawancara) dilakukan dalam pengumpulan dan analisis data. Hasil penelitian di Provinsi Banten menunjukkan bahwa semua indeks kualitas lingkungan berkorelasi dengan pemenuhan kebutuhan dasar, kecuali indeks keanekaragaman hayati. Berdasarkan uji korelasi didapatkan bahwa semua indeks kualitas lingkungan berpengaruh positif terhadap pemenuhan kebutuhan dasar. Hal ini berarti, apabila terjadi kenaikan kualitas udara, kualitas air, tutupan lahan, keanekaragaman hayati, kesehatan masyarakat, dan kesehatan lingkungan maka pemenuhan kebutuhan dasar akan meningkat, begitu juga sebaliknya. Indeks kualitas udara dan tutupan lahan mempunyai konstanta yang paling besar di antara indeks lainnya. Dengan demikian, kenaikan dari nilai tersebut akan berdampak lebih besar pada kenaikan pemenuhan dasar, demikian juga sebaliknya.
\end{abstract}

Kata kunci: kualitas lingkungan, kesehatan lingkungan, kebutuhan dasar 


\section{Pendahuluan}

Secara sederhana kualitas lingkungan hidup diartikan sebagai keadaan lingkungan yang dapat memberikan daya dukung optimal bagi kelangsungan hidup manusia pada suatu wilayah. Kualitas lingkungan dicirikan antara lain dari suasana yang membuat orang merasa betah atau kerasan tinggal di tempatnya sendiri. Lingkungan hidup yang baik dapat memungkinkan manusia berkembang secara optimal, secara selaras, serasi, dan seimbang. ${ }^{1}$

Sementara itu, berbagai keperluan hidup terpenuhi dari kebutuhan dasar atau primer, meliputi makan, minum, perumahan, sampai kebutuhan rohani atau spiritual meliputi pendidikan, rasa aman, dan sarana ibadah. Sebagaimana Pasal 28C ayat (1) UUD 1945 yang menyatakan bahwa setiap orang berhak mengembangkan diri melalui pemenuhan kebutuhan dasarnya, berhak mendapat pendidikan dan memperoleh manfaat dari ilmu pengetahuan dan teknologi, seni dan budaya, demi meningkatkan kualitas hidupnya dan demi kesejahteraan umat manusia (Suryani, 2017).

Pembangunan di Indonesia berhasil meningkatkan pendapatan nasional, akan tetapi keadaan ini mulai menimbulkan pencemaran dan kerusakan lingkungan hidup. Jika pencemaran dan kerusakan terus berlangsung, terbuka kemungkinan rusaknya lingkungan hidup. Kondisi sekarang menunjukkan telah terjadi penurunan kualitas dan daya dukung lingkungan yang cukup signifikan (Palupi, 2014). Selama ini, penilaian secara kuantitatif kualitas lingkungan hidup di Indonesia dapat didasarkan pada pedoman yang ada, yaitu laporan Kementerian Lingkungan Hidup dan Kehutanan yang berupa Indeks Kualitas Lingkungan Hidup (IKLH) Indonesia yang diterbitkan setiap tahun. Dalam laporan ini kualitas lingkungan hidup diindikasikan dengan tiga (3) kriteria, yaitu Indeks Kualitas Udara (IKU), Indeks Kualitas Air (IKA), dan Indeks Kualitas Tutupan Hutan/Lahan (IKTL). Berdasarkan Penghitungan IKLH Tahun

"Hak atas Lingkungan yang Baik dan Sehat," http://www. academia.edu/9614003/hak_atas_lingkungan_yang_baik dan_sehat, diakses 2 Februari 2018.
2016, Indeks kualitas lingkungan hidup nasional menunjukkan penurunan sebesar 2,50 poin dibandingkan dengan tahun 2015, yaitu dari 68,23 menjadi 65,73 . Hal ini dipengaruhi oleh penurunan nilai IKA sebesar 5,48 dibandingkan dengan tahun 2015, yaitu dari 65,86 menjadi 60,38 . Itu juga terjadi penurunan nilai IKU sebesar 2,23 poin dibandingkan tahun 2015, yaitu dari 83,84 menjadi 81,61. Nilai IKTL juga mengalami sedikit penurunan sebesar 0,47 poin dibandingkan dengan tahun 2015, yaitu dari 58,30 menjadi 57,83. Porsi penurunan nilai IKLH dari setiap komponen adalah $66 \%$ IKA, 27\% IKU dan 7\% IKTL (Kementerian Lingkungan Hidup dan Kehutanan, 2016).

Berdasarkan laporan IKLH Tahun 2016 tersebut, penurunan nilai IKA Nasional yang cukup signifikan ini paling besar merupakan kontribusi dari Provinsi Jawa Barat (77,95\%). Provinsi lain yang berkontribusi terhadap penurunan nilai IKA adalah Jawa Timur, Sulawesi Tengah, Nusa Tenggara Timur, Papua dan Maluku. Sementara itu, ada beberapa provinsi yang berkontribusi menahan laju penurunan IKA atau memiliki nilai IKA yang lebih baik bila dibandingkan dengan tahun sebelumnya, yaitu secara berturut-turut dimulai yang paling besar kontribusinya adalah Kalimantan Tengah, Banten, Sumatera Barat, Riau, Kalimantan Selatan dan Kalimantan Timur (Laporan Indeks Kualitas Lingkungan Hidup Tahun, 2016).

IKLH untuk setiap provinsi yang selama ini disusun mempunyai disparitas yang cukup tinggi. Berdasarkan data IKLH tahun 2016, IKLH tertinggi dimiliki oleh Provinis Papua Barat yakni sebesar 83,01. Sedangkan IKLH terendah adalah DKI Jakarta yakni sebesar 36,69. Lima provinsi dengan IKLH tertinggi setelah Papua Barat adalah Papua, Kalimantan Timur, Sulawesi Tenggara, Kalimantan Tengah dan Aceh. Sedangkan provinsi dengan IKLH terendah setelah DKI Jakarta adalah DI Yogyakarta, Jawa Barat, Nusa Tenggara Barat dan Riau (Laporan Indeks Kualitas Lingkungan Hidup Tahun, 2016). 
Adanya disparitas IKLH antara provinsi yang sangat besar dengan faktor utama penyebabnya adalah perbedaan luas tutupan lahan/hutan merupakan salah satu contoh adanya bias dalam penyusunan indeks kualitas lingkungan. Di mana tutupan lahan mempunyai bobot $40 \%$, lebih besar dari bobot pencemaran udara $(30 \%)$ dan pencemaran air (30\%). Berdasarkan perhitungan IKLH tahun 2016, semua provinsi di Pulau Jawa mempunyai IKLH lebih kecil dari IKLH ratarata nasional $(65,73)$. Penyebab utamanya adalah rendahnya indeks tutupan hutan di provinsi tersebut. Sementara itu, IKLH di Wilayah Timur seperti Papua, Papua Barat dan Maluku Utara memiliki indeks IKLH tertinggi di Indonesia, karena indeks tutupan hutannya tinggi. ${ }^{2}$

Dengan demikian, yang menjadi renungan selanjutnya adalah: apakah IKLH tersebut benar-benar menggambarkan kualitas lingkungan sesungguhnya di suatu wilayah? Jika dikatakan IKLH di Pulau Jawa rendah, namun pembangunan dari aspek lingkungan yang lain cukup baik di sini. Misalnya proporsi rumah tangga dengan akses terhadap fasilitas sanitasi dasar di beberapa provinsi di Pulau Jawa lebih tinggi daripada di Papua (Capaian MDGS 2015, Bappenas). Demikian juga Perilaku Hidup Bersih dan Sehat (PHBS) mempunyai indeks yang tinggi di Provinsi DKI Jakarta, Bali, dan DI Yogyakarta. Sementara itu, Provinsi Papua, Aceh dan NTT mempunyai indeks PHBS terendah di Indonesia (Riskesdas 2013) Perbedaan penilaian terhadap gambaran kondisi lingkungan tersebut disinyalir terjadi karena IKLH yang selama ini disusun belum memasukkan beberapa indikator penting dalam lingkungan hidup. Indikator-indikator tersebut antara lain: keanekaragaman hayati, kesehatan masyarakat, dan kesehatan lingkungan. Pengabaian aspek-aspek tersebut akan memberikan pemahaman yang bias terhadap kualitas lingkungan hidup yang sesungguhnya (Yuwono, 2016).

Indeks Kualitas Lingkungan Hidup Indonesia 2014. Kemeterian Lingkungan Hidup dan Kehutanan Republik Indonesia 2015.
Lebih lanjut lagi, sebuah kajian mengungkapan bahwa tidak terdapat hubungan antara IKLH dengan derajat kesejahteraan sosial (dalam kajian tersebut ditunjukkan oleh besaran Produk Domestik Regional Bruto (PDRB)). Antara keduanya tidak terdapat hubungan yang jelas (koefisien determinasinya yang sangat kecil). Beberapa provinsi dengan IKLH yang tinggi justru mempunyai PDRB yang rendah, misalnya Provinsi Gorontalo, Maluku Utara dan Maluku. Begitu juga sebaliknya, beberapa provinsi dengan PDRB tinggi mempunyai IKLH yang rendah, misalnya Provinsi DKI Jakarta, Banten dan Jawa Timur (Fauzi dkk., 2013).

Kemitraan partnership juga pernah melakukan pengukuran terhadap keterkaitan antara investasi, lingkungan hidup, dan pembangunan sumber daya manusia melalui pengukuran Indonesia Governance Index (IGI) yang memfokuskan pada performa pemerintah daerah. Kemitraan menyimpulkan bahwa provinsi dengan investasi tinggi tidak selalu menganggarkan pemeliharaan lingkungan secara proporsional. Misalnya data IGI menunjukkan nilai investasi Provinsi Jawa Barat merupakan yang tertinggi dari 32 provinsi yang ada di Indonesia, dengan indeks 9,33 namun kondisi lingkungannya berada pada rangking yang rendah (Gismar dkk., 2003, dalam Qodriyatun, 2016).

Berdasarkan kondisi tersebut, dapat dinyatakan bahwa IKLH yang ada disinyalir belum menggambarkan secara menyeluruh kondisi kualitas lingkungan hidup di suatu wilayah termasuk keanekaragaman hayati, kesehatan masyarakat dan kesehatan lingkungan. Demikian juga IKLH belum dapat menggambarkan keterkaitannya dengan derajat kesejahteraan sosial masyarakat khususnya dalam hal pemenuhan kebutuhan dasar. Oleh karena itu, perlu ditambahkan indikator kualitas lingkungan hidup termasuk keanekaragaman hayati, kesehatan masyarakat dan kesehatan lingkungan. Indikator tersebut diharapkan dapat menggambarkan kondisi lingkungan hidup dalam kaitannya dengan pemenuhan 
unsur ekologis, kebutuhan dasar manusia akan kesehatan dan lingkungan yang bersih, serta membangun wilayah/tempat/ bangunan yang memungkinkan warga negara dan masyarakat untuk meningkatkan dan mempertahankan kualitas hidup mereka, dan menciptakan kondisi untuk semua individu untuk mencapai potensi penuh mereka.

Berdasarkan permasalahan tersebut, yang menjadi pertanyaan penelitian ini adalah: bagaimana persepsi masyarakat dalam menilai pengaruh kualitas lingkungan terhadap pemenuhan kebutuhan dasar? Maksud dari penelitian ini adalah untuk menelaah pengaruh IKLH dengan mempertimbangkan dan menghitung ulang IKLH dengan beberapa indikator tambahan yakni: keanekaragaman hayati, kesehatan masyarakat, dan kesehatan lingkungan terhadap pemenuhan kebutuhan dasar masyarakat.

Adapun tujuan penelitian ini selain sebagai sarana untuk mengevaluasi efektivitas programprogram pengelolaan lingkungan dan peningkatan kesejahteraan, juga diharapkan dapat membantu perumusan kebijakan khususnya bidang lingkungan, membantu dalam mendesain program lingkungan yang berdampak langsung terhadap kesejahteran sosial, serta mempermudah komunikasi dengan publik sehubungan dengan kondisi lingkungan. Hasil kajian diharapkan dapat dimanfaatkan untuk mengukur dua keberhasilan sekaligus, yakni program-program pembangunan untuk meningkatkan kesejahteraan sosial dan kebijakan/ program dalam pengelolaan lingkungan.

Daerah yang dipilih dalam penelitian kali ini adalah Provinsi Banten. IKLH Provinsi Banten pada tahun 2016 adalah sebesar 60,00. Angka tersebut berada pada posisi 10 terendah dalam skala nasional. Apabila dilihat dari korelasi antara IKLH tahun 2012 dengan kapasitas pengelolaan lingkungan hidup per provinsi, maka Provinsi Banten berada pada kuadran III (kapasitas rendah, kualitas lingkungan hidup juga rendah). Penelitian di Provinsi Banten dilakukan pada tanggal 2 s.d. 8 Mei 2017 yang merupakan penelitian kelompok dengan tema Telaah terhadap Indikator Kesejahteraan Sosial dalam Bidang Lingkungan.

Penelitian ini menggabungkan dua desain (mixed method), yaitu eksplanasi (explanatory research) dan penelitian deskriptif (descriptive research). Objek telaahan penelitian eksplanasi adalah menguji hubungan antarvariabel yang dihipotesiskan kuantitatif dan kualitatif, sedangkan objek telaah penelitian deskriptif adalah eksplorasi dan klarifikasi mengenai sesuatu fenomena atau kenyataan sosial, dengan jalan mendeskripsikan sejumlah variabel yang berkenaan dengan masalah dan unit yang diteliti yakni kondisi lingkungan hidup dan derajat kesejahteraan masyarakat dalam hal ini yang meliputi aspek pemenuhan kebutuhan dasar.

Kuantifikasi terhadap berbagai indikator lingkungan beserta parameter-parameternya dilakukan untuk menghitung indeks kualitas lingkungan versi baru. Indeks kualitas lingkungan versi baru ini dianggap lebih komprehensif dan dianggap relevan dengan derajat kesejahteraan sosial khususnya dalam pemenuhan kebutuhan dasar masyarakat akan kualitas lingkungan yang lebih baik.

Teknik pengumpulan data dilakukan dengan mencari data-data sekunder bidang lingkungan dan kesehatan dari dokumen terkait di lokasi penelitian, wawancara dan penyebaran kuesioner. Data eksisting bidang lingkungan dan kesehatan digunakan sebagai input untuk menghitung indeks kualitas lingkungan versi baru. Pengumpulan data juga dilakukan dengan wawancara dengan stakeholder khususnya stakeholder di bidang lingkungan, kesehatan, dan sosial untuk menggali lebih jauh gambaran kualitas lingkungan dan derajat kesejahteraan masyarakat di lokasi penelitian. Informan pada penelitian ini antara lain: instansi terkait di lokasi penelitian (Bappeda, Badan Lingkungan Hidup, Dinas Kesehatan, Dinas Pekerjaan Umum dan Dinas Sosial) serta institusi lainnya seperti: unsur LSM, akademisi, atau organisasi non-pemerintah lainnya yang terkait.

Teknik pengumpulan data lainnya yang dilakukan adalah penyebaran kuesioner kepada responden yang terdiri dari masyarakat di 
Tabel 1. Variabel Dimensi dan Indikator Penelitian

\begin{tabular}{|c|c|c|c|}
\hline Variabel & Dimensi & Indikator & Item Pertanyaan \\
\hline \multirow{8}{*}{$\begin{array}{l}\text { Variabel } \boldsymbol{X} \\
\text { Indeks Kualitas } \\
\text { Lingkungan }\end{array}$} & Kualitas Udara & $\begin{array}{l}\mathrm{SO}_{2} \\
\mathrm{NO}_{2}\end{array}$ & 1,2 \\
\hline & Kualitas Air & $\begin{array}{l}\text { TSS (Total Suspended Solid) } \\
\text { DO (Dissolved Oxygen) } \\
\text { COD (Chemical Oxygen Demand) }\end{array}$ & $3,4,5,6$ \\
\hline & Tutupan Lahan/Hutan & $\begin{array}{l}\text { luas hutan primer (LHP) } \\
\text { luas hutan sekunder (LHS) }\end{array}$ & 7,8 \\
\hline & Keanekaragaman & Flora & 9,11 \\
\hline & Hayati & Fauna & 10,12 \\
\hline & Kesehatan Masyarakat & $\begin{array}{l}\text { Mortalitas } \\
\text { Morbiditas }\end{array}$ & $13,14,15,16,17,18$ \\
\hline & Kesehatan Lingkungan & $\begin{array}{l}\text { Akses terhadap air bersih } \\
\text { Rumah sehat }\end{array}$ & $\begin{array}{l}19 \\
20\end{array}$ \\
\hline & & Sanitasi dasar & 21 \\
\hline \multirow{12}{*}{$\begin{array}{l}\text { Variable } \boldsymbol{Y} \\
\text { Pemenuhan } \\
\text { kebutuhan dasar }\end{array}$} & Materi & $\begin{array}{l}\text { Pangan } \\
\text { Sandang } \\
\text { Papan }\end{array}$ & $\begin{array}{l}1 . \mathrm{A} \\
1 . \mathrm{B} \\
1 . \mathrm{C}\end{array}$ \\
\hline & \multirow{4}{*}{ Fisik } & Sarana prasarana kesehatan & 2.A \\
\hline & & Tenaga Kesehatan & 2.B \\
\hline & & Lingkungan yang bersih & 2.C \\
\hline & & $\begin{array}{l}\text { Ketersediaan fasilitas dan sarana prasarana } \\
\text { untuk pengelolaan samnah }\end{array}$ & $2 . \mathrm{E}$ \\
\hline & \multirow{4}{*}{ Mental } & Perasaan aman & $3 . \mathrm{A}$ \\
\hline & & Kesempatan pendidikan dasar dan menengah & 3.B \\
\hline & & Kesempatan pendidikan dasar dan menengah & 3.C \\
\hline & & Perasaan bahagia & 3.D \\
\hline & \multirow{3}{*}{ Spiritual } & Kekebasan beragama & 4.A \\
\hline & & Kesempatan aktualisasi diri & 4.B \\
\hline & & Kehidupan sosial & 4.C \\
\hline
\end{tabular}

lokasi penelitian. Tujuan penyebaran kuesioner ini adalah untuk mendapat gambaran persepsi masyarakat terkait kualitas lingkungan yang ada di daerahnya yang meliputi indikatorindikator yang dikaji dalam IKLH versi baru. Selain itu kuesioner akan menggali persepsi masyarakat terkait pemenuhan kebutuhan dasar yang selama ini dirasakan. Aspek-aspek yang ditinjau dalam pemenuhan kebutuhan dasar baik itu secara materi (sandang, pangan, dan papan), secara fisik (kesehatan, lingkungan yang bersih, termasuk air bersih), secara mental (seperti rasa aman, indeks kebahagiaan, dan pendidikan), dan secara spiritual (terpenuhinya kebutuhan untuk mengaktualisasikan diri dan hidup bersosial).

Persepsi masyarakat terhadap kualitas lingkungan hidup dengan indikator dan parameter yang baru dan hubungannya dengan pemenuhan kebutuhan dasar ditelaah dengan menyebarkan kuesioner kepada responden di lokasi penelitian.

Secara operasional, perlu didefinisikan variabel yang bertujuan untuk menjelaskan makna variabel penelitian. Singarimbun (1987: 23) mendefinisikan operasional sebagai unsur penelitian yang memberikan petunjuk bagaimana variabel itu diukur. Variabel harus didefinisikan secara operasional, agar lebih mudah ditemukan hubungan antara satu variabel dengan lainnya dan pengukurannya.

Dalam penelitian ini, variabel bebas (variabel $\mathrm{X})$ merupakan indeks kualitas lingkungan dan variabel tidak bebas (variabel Y) adalah pemenuhan dasar yang terdiri dari beberapa dimensi dan diturunkan lagi dalam beberapa indikator (lihat Tabel 1).

Teknik pengambilan sampel pada penelitian 
ini adalah nonprobability sampling, di mana tidak semua anggota populasi mempunyai kesempatan yang sama untuk menjadi sampel penelitian. Adapun populasi merupakan wilayah generalisasi yang terdiri atas objek/subjek yang mempunyai kuantitas dan karakteristik tertentu, yang ditetapkan oleh peneliti untuk dipelajari dan ditarik kesimpulan. Responden diasumsikan masyarakat yang paham dan dapat menggambarkan persepsi mereka terkait kualitas lingkungan dan pemenuhan kebutuhan dasar di daerahnya. Dengan demikian, pegawai pemerintahan pada dinas di instansi terkait, LSM, akademisi, tokoh masyarakat, dan juga masyarakat yang paham akan kondisi lingkungan dan kesejahteraan merupakan populasi pada penelitian ini.

Sampel adalah sebagian dari jumlah dan karakteristik yang dimiliki oleh populasi tersebut. Oleh karena itu, sampel yang akan diambil dari populasi harus betul-betul representatif (dapat mewakili). Agar hasil penelitian yang dilakukan terhadap sampel masih tetap dapat dipercaya, atau masih dapat mewakili karakteristik populasi, maka penarikan sampel harus dilakukan secara seksama.

Sampling penelitian ini dilakukan dengan teknik incidental sample atau accidental sampling, di mana pemilihan partisipan didasarkan pada ketersediaan atau kemudahan mengakses populasi partisipan (Kumar, 1999). Sampel dipilih berdasarkan karakteristik yang paling mendekati dan mudah didapat (Guilforf \& Fruuncher, 1978). Kelemahan teknik ini adalah hasil yang diperoleh tidak dapat digeneralisir pada populasi secara keseluruhan, dan orang yang paling mudah dijangkau mungkin tidak benar-benar representatif untuk populasi (Kumar, 1999).

Jumlah partisipan penelitian yang direncanakan dalam penelitian ini adalah minimal 30 orang. Menurut Guilford dan Frucher (1978) pengambilan jumlah sampel yang baik untuk suatu penelitian adalah setidaknya 30 orang, sehingga data dapat dianalisis secara statistik dengan menggunakan distribusi normal. Selain itu, jumlah sampel yang semakin besar dapat mengurangi varian eror dalam uji statistik, sehingga hasil yang diperoleh akan semakin akurat dibandingkan penelitian dengan jumlah sampel yang sedikit.

Sebagaimana sudah dijelaskan pada desain penelitian, teknik pengumpulan data utama dalam penelitian ini adalah melalui: kuesioner, wawancara, dan studi dokumentasi (untuk menghitung IKLH versi baru). Kuesioner adalah suatu daftar yang berisikan suatu rangkaian pertanyaan untuk memperoleh data berupa jawaban-jawaban yang mempunyai skala dari para responden (orang-orang yang menjawab). Adapun skala yang digunakan adalah skala likert. Tentang format skala likert tersebut, J. Supranto (1997) menjelaskan sebagai berikut:

"Untuk memungkinkan para responden
menjawab dalam berbagai tingkatan bagi
setiap butir kepuasan, format tipe likert
bisa dipergunakan. R.A. Likert (1932)
mengembangkan prosedur penskalaan
di mana skala mewakili suatu kontinum
bipolar. Pada ujung sebelah kiri (dengan
angka rendah) menggambarkan suatu
jawaban yang negatif sedangkan
ujung kanan (dengan angka besar)
menggambarkan yang positif."

Dengan format skala likert tersebut akan memberikan skor secara konsisten pada setiap jawaban yang dipilih oleh setiap responden penelitian. Selanjutnya keseluruhan skor pada setiap pilihan jawaban responden akan dimasukan ke dalam tabel distribusi jawaban responden.

Analisis data dilakukan dengan terlebih dahulu menguji validitas instrumen penelitian. Menurut Sujana (2004) validitas adalah ketepatan alat penilaian terhadap konsep yang dinilai sehingga betul-betul menilai apa yang harus dinilai. Validitas menunjukkan sejauh mana suatu alat pengukur itu mengukur apa yang diukur. Sehubungan dengan pengumpulan data dalam penelitian ini dilakukan dengan menggunakan kuesioner, maka kuesioner yang disusun tersebut harus dapat teruji validitasnya. Selanjutnya melakukan uji reliabilitas instrumen penelitian. Reliabilitas adalah indeks yang menunjukkan sejauh 
mana suatu alat pengukur dapat dipercaya atau dapat diandalkan. Bila suatu alat pengukur dipakai dua kali untuk mengukur gejala yang sama dan hasil pengukuran yang diperoleh relatif konsisten, maka alat pengukur tersebut reliabel.

Menurut Sugiyono (2012) butir yang mempunyai korelasi positif dengan kriterium (skor total) serta korelasi yang tinggi, menunjukkan bahwa butir tersebut mempunyai validitas yang tinggi pula. Syarat minimum untuk dianggap memenuhi syarat adalah jika $\mathrm{r}=0,3$.

Untuk membahas data yang diperoleh melalui proses kegiatan penelitian, penulis menggunakan metode analisis deskriptif kuantitatif. Penelitian deskriptif dilakukan untuk mendeskripsikan suatu gejala, peristiwa, dan kejadian yang terjadi secara faktual, sistematis, dan akurat. Menurut Sugiyono (2008), penelitian deskriptif adalah penelitian yang dilakukan untuk mengetahui nilai variabel mandiri, baik satu variabel atau lebih (independen) tanpa membuat perbandingan atau menghubungkan dengan variabel yang lain. Penelitian deskriptif kuantitatif menggambarkan data kuantitatif yang diperoleh menyangkut keadaan subjek atau fenomena dari sebuah populasinya. Penelitian ini juga melakukan interpretasi dan pengukuran atas data-data hasil penelitian yang berwujud angka-angka atau bilangan tertentu.

\section{Pemenuhan Kebutuhan Dasar}

King (1987 dalam Potter, 2005) mengatakan bahwa pemenuhan kebutuhan dasar manusia berfokus pada tiga sistem yakni, sistem personal, interpersonal, dan sistem sosial. Atau dengan kata lain, manusia berusaha menstimulasi respons dalam mencapai keseimbangan. Setiap orang mempunyai kebutuhan dasar yang sama, walaupun masing-masing memiliki latar belakang sosial, budaya, persepsi, dan pengetahuan yang berbeda. Manusia akan memenuhi kebutuhan dasarnya sesuai dengan tingkat prioritas masingmasing. Kebutuhan dasar yang harus segera dipenuhi adalah kebutuhan dasar dengan tingkat prioritas yang paling tinggi/utama.

Watson (dalam Kasiati dan Rosmalawati, 2016) berpendapat lain, bahwa kebutuhan dasar terdiri dari 4 hal, yakni kebutuhan biofisikal (kebutuhan makanan dan minuman, kebutuhan eliminasi, dan kebutuhan ventilasi), kebutuhan psikofisikal (kebutuhan aktivitas, istirahat dan kebutuhan seksual), kebutuhan psikososial (kebutuhan berorganisasi dan berprestasi), dan kebutuhan interpersonal dan intrapersonal (kebutuhan aktualisasi diri).

Manusia sebagai makhluk holistik merupakan makhluk yang utuh atau paduan dari unsur biologis, psikologis, sosial, dan spiritual. Sebagai makhluk biologis, manusia tersusun atas sistem organ tubuh yang digunakan untuk mempertahankan hidupnya, mulai dari lahir, tumbuh kembang, hingga meninggal. Sebagai makhluk psikologis, manusia mempunyai struktur kepribadian, tingkah laku sebagai manifestasi kejiwaan, dan kemampuan berpikir serta kecerdasan. Sebagai makhluk sosial, manusia perlu hidup bersama orang lain, saling bekerja sama untuk memenuhi kebutuhan dan tuntutan hidup, mudah dipengaruhi kebudayaan, serta dituntut untuk bertingkah laku sesuai dengan harapan dan norma yang ada. Sebagai makhluk spiritual, manusia memiliki keyakinan, pandangan hidup, dan dorongan hidup yang sejalan dengan keyakinan yang dianutnya (Kasiati dan Rosmalawati, 2016).

Kebutuhan dasar manusia merupakan unsurunsur yang dibutuhkan oleh manusia dalam mempertahankan keseimbangan fisiologis maupun psikologis, yang tentunya bertujuan untuk mempertahankan kehidupan dan kesehatan yang pada akhirnya dapat mencapai derajat kesejahteraan.

Berdasarkan Undang-Undang Nomor 11 Tahun 2009 tentang Kesejahteraan Sosial, kesejahteraan sosial adalah kondisi terpenuhinya kebutuhan material, spiritual dan sosial warga negara agar dapat hidup layak dan mampu mengembangkan diri sehingga dapat melaksanakan fungsi sosialnya. Hal ini berarti kesejahteraan 
masyarakat dapat diukur dari terpenuhinya berbagai kebutuhan hidupnya, baik itu secara materi (sandang, pangan, dan papan), secara fisik (kesehatan, lingkungan yang bersih, termasuk air bersih), secara mental (seperti rasa aman dan pendidikan), serta secara spiritual (terpenuhinya kebutuhan untuk mengaktualisasikan diri dan hidup bersosial) (Hidayat, 2016). Pembangunan kesejahteraan sosial sebagaimana diatur dalam UU tersebut dimaksudkan untuk mewujudkan kehidupan yang layak dan bermartabat, serta untuk memenuhi hak atas kebutuhan dasar warga negara.

\section{Indikator Kualitas Lingkungan Hidup}

Kualitas lingkungan hidup saat ini dinilai secara kuantitatif menggunakan Indeks Kualitas Lingkungan Hidup (IKLH). IKLH ini diadopsi dari beberapa sumber di antaranya Environmental Performance Index (EPI) yang dikembangkan oleh sebuah pusat studi di Yale University, yaitu Yale Center for Environmental Law and Policy beserta Columbia University (Center for International Earth Science Information Network) yang berkolaborasi dengan World Economic Forum dan Joint Research Center of the European Commission. Indeks Kualitas Lingkungan Hidup (IKLH) merupakan publikasi yang menggambarkan kondisi lingkungan hidup Indonesia (Suryani, 2017). IKLH dapat digunakan untuk mengevaluasi secara umum kualitas lingkungan hidup dan tren pencapai tujuan pembangunan berkelanjutan di Indonesia. IKLH difokuskan pada media lingkungan air, udara, dan tutupan lahan.

\section{Kualitas Udara}

Kualitas udara dinyatakan dalam bentuk Indeks Pencemaran Udara (IPU). Parameter kualitas udara yang dimasukkan dalam perhitungan hanya dua (2), yaitu $\mathrm{SO}_{2}$ dan $\mathrm{NO}_{2}$, meskipun parameter kualitas udara ambien memiliki sembilan (9) parameter. Dua parameter tersebut diambil mengingat pencemaran udara di perkotaan sebagian besar disebabkan oleh sektor transportasi. Dua parameter ini juga merupakan sebagian kecil dari parameter kualitas udara ambien yang masuk dalam Peraturan Pemerintah Nomor 41 Tahun 1999 tentang Pengendalian Pencemaran Udara. Dalam PP tersebut, parameter kualitas udara meliputi $\mathrm{SO}_{2}, \mathrm{CO}, \mathrm{NO}_{2}, \mathrm{O}_{3}, \mathrm{~Pb}$, debu jatuh (dustfall), TSP (Total Suspended Particulate), $\mathrm{PM}_{2.5}$ dan $\mathrm{PM}_{10}$ (Particulate Matter), dan hidrokarbon (HC).

\section{Kualitas Air}

Kualitas air dinyatakan dalam bentuk Indeks Pencemaran Air (IPA). Parameter kualitas air yang dihitung dalam IPA guna memperoleh IKLH hanya mencakup tiga (3) parameter saja, yaitu TSS (Total Suspended Solid), DO (Dissolved Oxygen), dan COD (Chemical Oxygen Demand). Pemilihan parameter TSS, DO, dan COD didasarkan pada ketersediaan data setiap tahunnya. Sebagai perbandingan, parameter kualitas air yang ada dalam Peraturan Pemerintah Nomor 82 Tahun 2001 tentang Pengelolaan Kualitas Air dan Pengendalian Pencemaran Air mencakup 47 parameter yang terdiri dari tiga (3) parameter fisika, 27 parameter kimia anorganik, dua (2) parameter mikrobiologi, dua (2) parameter radioaktivitas, dan 13 parameter kimia organik.

\section{Tutupan Hutan}

Tutupan hutan dinyatakan dalam bentuk Indeks Tutupan Hutan (ITH) yang dihitung berdasarkan jumlah luas hutan primer (LHP) dan luas hutan sekunder (LHS) yang ditetapkan oleh Menteri Kehutanan terhadap Luas Wilayah Provinsi (LWP). LHP ditambah LHS sama dengan LTH. Hutan primer adalah hutan yang belum mendapatkan gangguan manusia atau sedikit sekali mendapat gangguan. Hutan sekunder adalah hutan yang tumbuh melalui suksesi sekunder alami pada lahan hutan yang telah mengalami gangguan berat seperti lahan bekas pertambangan, peternakan, dan pertanian menetap. 


\section{Penyempurnaan Perhitungan IKLH dan} Kaitannya dengan Kesejahteraan Sosial

Penilaian atas indeks kualitas lingkungan di atas sebenarnya hanya merupakan sebagian indikator kualitas lingkungan hidup karena masih ada beberapa parameter penting dalam lingkungan hidup yang perlu dimasukkan sebagai indikator kualitas lingkungan, yaitu: keanekaragaman hayati (flora dan fauna), kesehatan masyarakat, dan kesehatan lingkungan. Ketiga parameter beserta ukuran kuantitatifnya dapat dinyatakan sebagai berikut:

- Flora dan fauna dinyatakan dengan Indeks Keanekaragaman Hayati (IKH)

- Kesehatan masyarakat dinyatakan dalam Indeks Kesehatan Masyarakat (IKM)

- Kesehatan lingkungan dinyatakan dalam Indeks Kesehatan Lingkungan (IKL).

\section{Keanekaragaman Hayati}

Keanekaragaman alam hayati menunjukkan berbagai variasi dalam bentuk, struktur tubuh, warna, jumlah, dan sifat lain dari makhluk hidup di suatu daerah. Sumber Daya Alam (SDA) hayati merupakan bagian dari mata rantai tatanan lingkungan hidup, yang menjadikan lingkungan ini hidup dan mampu menghidupkan manusia dari generasi ke generasi. Makin beranekaragam sumber ini, makin banyak hikmah dan pilihan bagi manusia untuk memenuhi kebutuhan hidupnya. ${ }^{3}$

Istilah keanekaragaman hayati (ragam hayati, keanekaan hayati, biodiversitas, atau biodiversity) merupakan istilah yang digunakan untuk derajat keanekaragaman SDA hayati yang meliputi jumlah maupun frekuensi dari ekosistem, spesies, maupun gen di suatu daerah. Pengertian yang lebih mudah dari keanekaragaman hayati adalah kelimpahan berbagai jenis SDA hayati (tumbuhan dan hewan) yang terdapat di muka bumi. ${ }^{4}$

\footnotetext{
3 "Modul I Keanekaragaman Hayati," http://file. upi.edu/direktori/fpmipa/_ jur._pend._biologi/ 195305221980021-suroso_adi_yudianto/modul/modul1_ keanekaragaman_hayati.pdf, diakses 2 Maret 2017.

4 "Keanekaragaman Hayati Kondisi dan Permasalahannya,"

Keanekaragaman hayati adalah tergolong SDA yang dapat diperbarui, karena dapat dikembangbiakan, baik secara seksual (generatif), aseksual (vegetatif), maupun secara paraseksual (perkawinan sel vegetatif untuk menghasilkan sel poliploidi atau melalui upaya rekayasa genetika). Namun demikian, SDA hayati dapat saja semakin sedikit dan akhirnya menjadi punah, apabila pengelolaannya tidak memperhatikan pelestariannya sebagaimana makhluk hidup purba yang mengalami nasib kepunahan. Kekhawatiran ini semakin nyata, terbukti beberapa jenis makhluk hidup di Indonesia sudah diambang kepunahan.

\section{Kesehatan Masyarakat}

Pengertian kesehatan masyarakat menurut Winslow (dalam Notoatmodjo, 2007) bahwa kesehatan masyarakat (Public Health) merupakan ilmu dan seni: mencegah penyakit, memperpanjang hidup, dan meningkatkan kesehatan, melalui "usaha-usaha pengorganisasian masyarakat " untuk:

1. Perbaikan sanitasi lingkungan;

2. Pemberantasan penyakit-penyakit menular;

3. Pendidikan untuk kebersihan perorangan;

4. Pengorganisasian pelayanan-pelayanan medis dan perawatan untuk diagnosis dini dan pengobatan;

5. Pengembangan rekayasa sosial untuk menjamin setiap orang terpenuhi kebutuhan hidup yang layak dalam memelihara kesehatannya.

Dari batasan tersebut tersirat bahwa kesehatan masyarakat adalah kombinasi teori (ilmu) dan praktik (seni). Dari aspek keilmuan, kesehatan masyarakat pada mulanya hanya mencakup dua disiplin keilmuan yaitu ilmu biomedis dan ilmu sosial. Akan tetapi sesuai dengan perkembangan ilmu, maka disiplin ilmu yang mendasari kesehatan masyarakatpun berkembang. Secara garis besar disiplin ilmu yang mendasari ilmu kesehatan masyarakat antara lain epidemiologi, biostatistik, kesehatan lingkungan, pendidikan kesehatan

http://ani_mardiastuti.staff.ipb.ac.id/files/ 2011/09/kehatidan-permasalahannya.pdf, diakses 2 Maret 2017. 
dan ilmu perilaku, administrasi kesehatan masyarakat, gizi masyarakat dan kesehatan kerja (Notoatmodjo, 2007).

Menurut Achmadi (2013) kesehatan masyarakat adalah semua upaya yang bertujuan untuk meningkatkan derajat kesehatan dengan menggunakan serangkaian upaya yang sekurang-kurangnya terdiri dari unsur-unsur:

1. Berbasis masyarakat;

2. Berorientasi pencegahan dan peningkatan derajat kesehatan;

3. Dilaksanakan secara lintas disiplin atau bekerja sama dengan sektor non-kesehatan;

4. Adanya keterlibatan masyarakat atau partisipasi masyarakat;

5. Terorganisir dengan baik.

Masalah kesehatan masyarakat adalah suatu masalah yang sangat kompleks yang saling berkaitan dengan masalah-masalah lain di luar kesehatan. Hendrik L. Bloom menyatakan secara ringkas faktor yang memengaruhi kesehatan antara lain faktor keturunan (genetik), pelayanan kesehatan, perilaku kesahatan dan lingkungan (fisik, sosial, ekonomi, budaya, dan lainnya). Masalah kesehatan masyarakat juga merupakan multikausal maka pemecahannya harus secara multidisiplin. Oleh karena itu, kesehatan masyarakat sebagai seni atau praktik mempunyai bentangan yang luas. Semua kegiatan baik yang langsung maupun tidak langsung untuk mencegah penyakit (preventif), meningkatkan kesehatan (promotif), terapi atau kuratif (fisik, mental dan sosial), maupun pemulihan kesehatan atau rehabilitatif (fisik, mental, dan sosial) merupakan upaya kesehatan masyarakat (dalam Notoatmodjo, 2007).

Tujuan umum kesehatan masyarakat adalah terciptanya keadaan lingkungan yang sehat, terberantasnya penyakit menular, meningkatnya pengetahuan masyarakat tentang prinsip-prinsip kesehatan perseorangan, tersedianya berbagai usaha kesehatan yang dibutuhkan masyarakat yang terorganisir dan terlibatnya badan-badan kemasyarakatan dalam usaha kesehatan. Sedangkan tujuan akhirnya adalah terciptanya jaminan bagi tiap individu masyarakat untuk mencapai suatu derajat hidup yang cukup guna untuk mempertahankan kesehatan. $^{5}$

Untuk dapat melihat suatu derajat atau status kesehatan masyarakat dapat digunakan indikator mortalitas (kematian), morbiditas (kesakitan) dan status gizi. Hal ini dikarenakan sensitivitasnya terhadap perbaikan pelayanan kesehatan baik dari sisi aksesibilitas maupun kualitas. Mortalitas terdiri dari Angka Kematian Bayi (AKB), Angka Kematian Balita (AKABA) dan Angka Kematian Ibu (AKI). Morbiditas terdiri dari angka kesakitan beberapa penyakit utama.

Saat ini, mortalitas erat dikaitkan dengan perubahan iklim. Berbagai penyakit infeksi akibat perubahan iklim merupakan salah satu penyebab atau pemberi kontribusi terhadap AKI dan AKB. AKI dan AKB merupakan akibat lebih jauh dari kejadian sakit. Penyebab utama mortalitas di Indonesia masih didominasi oleh penyakit menular, berkenaan dengan determinan utama kemiskinan dan sanitasi lingkungan yang buruk. Diare dan penyakit infeksi merupakan penyebab utama kematian bayi. Semua penyebab kematian tersebut dapat dicegah dengan penyediaan air bersih, rumah sehat, dan sanitasi dasar lainnya (Achmadi, 2013).

Dalam penyempurnaan indeks kualitas lingkungan yang dimaksud disini, aspek kesehatan masyarakat menyangkut indikator seperti angka kesakitan, angka kematian, dan umur harapan hidup (UHH). Angka kesakitan (prevalensi penyakit) adalah banyaknya kasus penyakit tertentu setiap sepuluh ribu (10.000) penduduk. Angka kematian terdiri dari angka kematian bayi, angka kematian balita, dan angka kematian ibu melahirkan. Umur harapan hidup (UHH), yaitu perkiraan jumlah tahun hidup dari individu (manusia) yang berdiam di suatu wilayah, lazimnya sudah dihitung dan tersedia di setiap kabupaten/kota di Indonesia.

Sesuai dengan Keputusan Menteri Kesehatan No. 1202/Menkes/SK/VIII/ 2003

\footnotetext{
"Definisi Kesehatan Masyarakat," https://www.academia. edu/8278738/Definisi_Kesehatan_ Masyarakat, diakses 3 Maret 2017.
} 
tentang Indikator Indonesia Sehat 2010 dan Pedoman Penetapan Indikator Provinsi Sehat dan Kabupaten/Kota Sehat, indikator derajat kesehatan masyarakat terdiri atas indikator mortalitas, indikator morbiditas, dan indikator status gizi. Indikator-indikator tersebut merupakan acuan bagi berbagai pihak pemangku kepentingan dalam mendapatkan kesamaan tolok ukur.

\section{Kesehatan Lingkungan}

Kesehatan lingkungan merupakan ilmu kesehatan masyarakat yang menitikberatkan usaha preventif dengan usaha perbaikan semua faktor lingkungan agar manusia terhindar dari penyakit dan gangguan kesehatan. Kesehatan lingkungan adalah karakteristik dari kondisi lingkungan yang mempengaruhi derajat kesehatan. Untuk itu kesehatan lingkungan merupakan salah satu dari enam usaha dasar kesehatan masyarakat. Menurut WHO (World Health Organization), kesehatan lingkungan adalah suatu keseimbangan ekologi yang harus ada antara manusia dan lingkungan agar dapat menjamin keadaan sehat dari manusia. ${ }^{6}$ Kesehatan lingkungan sangat erat hubungannya dengan taraf sosial ekonomi, karenanya untuk dapat mengelola kualitas lingkungan dan kesehatan masyarakat perlu dihayati hubungan timbal balik antara lingkungan dengan manusia (Soemirat, 2011). Kondisi lingkungan yang baik adalah yang mampu menopang keseimbangan ekologi yang dinamis antara manusia dan lingkungannya untuk mendukung tercapainya kualitas hidup manusia yang sehat dan bahagia.

Masalah kesehatan lingkungan di negaranegara sedang berkembang adalah berkisar pada sanitasi (jamban), penyediaan air minum, perumahan, pembuangan sampah, dan pembuangan air limbah (Notoatmodjo, 2007). Di Indonesia, ruang lingkup kesehatan lingkungan diterangkan dalam Pasal 22 ayat (3) UU No 23 Tahun 1992 terdiri dari 8 aspek, yaitu:

1. Penyehatan Air dan Udara

World Health Organization (WHO). Environmental Health. Disitasi dari :http://www.WHO.int, diakses 1 Maret 2017.
2. Pengamanan Limbah padat/sampah

3. Pengamanan Limbah cair

4. Pengamanan limbah gas

5. Pengamanan radiasi

6. Pengamanan kebisingan

7. Pengamanan vektor penyakit

8. Penyehatan dan pengamanan lainnya, seperti keadaan pasca bencana

Istilah kesehatan lingkungan seringkali dikaitkan dengan istilah sanitasi/sanitasi lingkungan. WHO menyebutkan pengertian sanitasi lingkungan/kesehatan lingkungan adalah suatu usaha untuk mengawasi beberapa faktor lingkungan fisik yang berpengaruh kepada manusia, terutama terhadap hal-hal yang mempunyai efek merusak perkembangan fisik, kesehatan dan daya tahan hidup manusia (Haryoto, 1986).

Dalam perhitungan IKLH baru, aspek kesehatan lingkungan mencakup komponenkomponen sebagai berikut:

1) Persentase keluarga yang memiliki akses air bersih;

2) Persentase rumah sehat;

3) Persentase keluarga yang memiliki sarana sanitasi dasar.

Semua aspek di atas merupakan aspek penting yang bersifat mendasar dan karenanya merupakan parameter penting dalam sistem penilaian kualitas lingkungan hidup. Bila penilaian kualitas lingkungan hidup tidak melibatkan aspek-aspek tersebut maka nilai yang muncul tidak bisa menunjukkan sifat yang representatif. Pengabaian aspek-aspek tersebut juga akan memberikan pemahaman yang bias terhadap kualitas lingkungan hidup yang sesungguhnya. Pelibatan ketiga aspek ini (flora dan fauna, kesehatan masyarakat, dan kesehatan lingkungan) akan membawa implikasi positif berupa perluasan kriteria penilaian kualitas lingkungan hidup dibandingkan dengan kriteria penilaian yang berlangsung selama ini.

Salah satu implikasi positif yang nyata dan bisa segera dilihat adalah adanya perhatian dari masyarakat dan berbagai pihak yang terlibat (stakeholders) bahwa berbagai aspek tersebut juga menjadi salah satu 
Tabel 2. IPM Provinsi Banten Tahun 2011-2013

\begin{tabular}{lccccccc}
\hline \multicolumn{1}{c}{$\begin{array}{c}\text { Kabupate/kota } \\
\text { Regency/Municipality }\end{array}$} & \multicolumn{3}{c}{ IPM/HDI } & \multicolumn{3}{c}{ Reduksi Shortfall/Reducation } \\
\cline { 2 - 7 }$(1)$ & $\mathbf{2 0 1 1}$ & $\mathbf{2 0 1 2}$ & $\mathbf{2 0 1 3}$ & $\mathbf{2 0 1 1}$ & $\mathbf{2 0 1 2}$ & $\mathbf{2 0 1 3}$ \\
\cline { 2 - 7 } & & $(3)$ & $(4)$ & $(5)$ & $(6)$ & $(7)$ \\
\hline Kabupaten / Regency & 68,77 & 68,22 & 69,64 & 1,54 & 1,43 & 1,36 \\
1. Pandeglang & 67,98 & 68,43 & 68,82 & 0,96 & 1,41 & 1,25 \\
2. Lobak & 72,05 & 72,36 & 72,82 & 1,02 & 1,10 & 1,66 \\
3. Tanggerang & 69,33 & 69,83 & 70,25 & 2,09 & 1,64 & 1,38 \\
4. Serang & & & & & & \\
Kota / Municipality & 75,44 & 75,72 & 76,05 & 1,12 & 1,13 & 1,34 \\
5. Tanggerang & 75,60 & 75,89 & 76,31 & 1,23 & 1,21 & 1,75 \\
6. Cilegon & 71,45 & 72,30 & 73,12 & 2,86 & 2,98 & 2,95 \\
7. Serang & 76,01 & 76,61 & 77,13 & 2,56 & 2,52 & 2,21 \\
8. Tanggerang Selatan & 70,95 & 71,49 & 71,90 & 1,56 & 1,87 & 1,45 \\
Provinsi Banten & & & & & & \\
\hline SUnyyyyyyy
\end{tabular}

Sumber: Banten Dalam Angka 20145

ukuran kualitas lingkungan. Bila nilai dari suatu aspek rendah maka masyarakat akan tergerak untuk berupaya memperbaikinya. Dan sebaliknya, bila nilai yang diperoleh dari aspek-aspek yang tercakup telah relatif tinggi, maka masyarakat akan berupaya untuk terus mempertahankan atau bahkan meningkatkannya.

Nilai ketiga aspek atau parameter di atas dapat diperoleh berdasarkan data yang dimiliki oleh masing-masing kabupaten/ kota yang lazimnya dikemas dalam bentuk Laporan Status Lingkungan Hidup (SLH) atau State of the Environment Report (SoER). Ketiga indeks tersebut diharapkan dapat juga dihitung secara langsung berdasarkan data pendukung yang ada. Dengan demikian, rangkaian data tersebut harus tersedia di setiap kabupaten/kota dan provinsi.

Oleh karena itu, dengan memasukkan tiga indikator baru dalam menghitung indeks kualitas lingkungan diasumsikan indeks kualitas lingkungan tersebut akan lebih komprehensif. Namun demikian, permasalahan memasukkan atau tidak memasukkan tiga indikator terakhir diatas tidak hanya berhenti di sini, melainkan perlu mempertimbangkan ketersediaan data dan keberlangsungan penyediaannya di seluruh Indonesia. Salah satu masalah klasik dan mendasar yang menyangkut aspek data di Indonesia adalah ketersediaannya secara terus menerus (series data).

\section{Gambaran Umum Provinsi Banten}

\section{Indikator Pembangunan Manusia dan Sosial Ekonomi}

Provinsi Banten memiliki jumlah penduduk yang cukup signifikan, dengan jumlah kelahiran yang cukup tinggi. Sebaran penduduk yang tidak merata dengan aktivitas yang tidak terkontrol mampu menstimulasi konflik-konflik di masyarakat, baik konflik vertikal maupun horizontal. Oleh karena itu, hal ini menjadi salah satu faktor yang harus menjadi pertimbangan utama di dalam penyusunan setiap program dengan tujuan menghasilkan sumber daya manusia yang berkompeten. Jumlah penduduk Provinsi Banten berdasarkan hasil rekapitulasi dari data Kabupaten dan Kota se-Provinsi Banten yang dilakukan oleh Biro Pemerintahan Setda Provinsi Banten pada Semester II Tahun 2014 adalah 10.016 .587 jiwa. $^{7}$

https://bantenprov.go.id/upload/llpd/Materi\%20ILPPD\%20 2014.pdf diakses 15 September 1017. 
Persebaran penduduk di Banten tidak merata, karena masih terkonsentrasi di wilayah Kabupaten Tangerang, Kota Tangerang, dan Kota Tangerang Selatan. Dengan luas wilayah kurang dari 14 persen dari seluruh luas wilayah Provinsi Banten, ketiga wilayah tersebut pada tahun 2014. Akibatnya tingkat kepadatan penduduk antar wilayah di Banten menjadi sangat tidak merata. Tercatat, Kota Tangerang merupakan wilayah dengan tingkat kepadatan tertinggi, mencapai 12.147 jiwa per $\mathrm{km}^{2}$, sedangkan yang terendah adalah Kabupaten Lebak yaitu dengan tingkat kepadatan penduduk hanya 359 jiwa per $\mathrm{km}^{2}$. Berarti, Kota Tangerang hampir 34 kali lebih padat bila dibandingkan dengan Kabupaten Lebak.

Pembangunan manusia merupakan sebuah proses perubahan kualitas manusia menuju kehidupan yang lebih baik. Kemajuan manusia secara umum dapat ditunjukkan dengan melihat perkembangan Indeks Pembangunan Manusia (IPM) yang mencerminkan kemajuan pada tiga dimensi pokok pembangunan manusia yaitu bidang Pendidikan, Kesehatan, dan Ekonomi. Capaian pembangunan manusia di Provinsi Banten selama Periode 2011 - 2013 secara keseluruhan mengalami peningkatan, walaupun lambat. Hal ini terlihat bukan hanya dari angka IPM yang meningkat tidak terlalu tinggi jika di bandingkan dengan IPM pada tahun 2011 ke tahun 2012. Begitu juga dapat dilihat dari penurunan reduksi shortfall dari 1,87 pada tahun 2012 menjadi 1,45 pada tahun 2013. Implikasi dari membesar atau menurunnya reduksi shortfall ini adalah salah satu indikator menuju IPM ideal $(\mathrm{IPM}=100)$. IPM Provinsi Banten pada tahun 2013 sendiri baru mencapai 71,90 atau jarak dari IPM ideal masih kurang 28,10 persen. $^{8}$

Pertumbuhan ekonomi Provinsi Banten pada triwulan III 2016 tumbuh sebesar 5,35 persen, lebih tinggi dari nasional sebesar 5,02 persen. Pertumbuhan ekonomi Banten yang melebihi angka nasional tersebut antara lain ditunjang oleh perkembangan investasi baik Penanaman Modal Asing (PMA) maupun Penanaman Modal Dalam Negeri (PMDN)

$$
\text { Ibid. }
$$

yang cukup tinggi. Secara peringkat investasi Provinsi Banten berada di urutan ke-4 secara nasional untuk Penanaman Modal Asing (PMA) dan urutan ke-3 untuk Penanaman Modal Dalam Negeri (PMDN). Membaiknya kinerja ekspor juga mendorong tumbuhnya industri pengolahan komitmen pemerintah dalam mendorong Tingkat Kandungan Dalam Negeri (TKDN) pada proyek-proyek infrastruktur juga telah berdampak pada kinerja industri pengolahan di Provinsi Banten. ${ }^{9}$

Dari sisi perkembangan harga, inflasi di Provinsi Banten terjaga di level yang rendah dan stabil. Inflasi sampai dengan November tercatat di level 3,33 persen, lebih rendah dari posisi yang sama tahun 2015 yang mencapai 5,86 persen, sedangkan untuk pertumbuhan perekonomian Provinsi Banten untuk 2017 sebesar 5,2-5,5 persen dan untuk tingkat inflasi Banten pada tahun 2017 diperkirakan dalam kisaran 4,5-4,8 persen. Reformasi struktural yang berjalan dengan baik akan meningkatkan produktivitas dan mendorong perekonomian tumbuh lebih tinggi. Kinerja perekonomian yang tumbuh tinggi dan disertai struktur yang lebih baik pada gilirannya akan meningkatkan penyerapan tenaga kerja dan menghindarkan perekonomian dari jebakan kelas menengah (middle income trap) ${ }^{10}$

\section{Derajat Kesehatan Masyarakat}

Kesehatan merupakan hak asasi manusia sebagaimana tertera dalam Pasal $28 \mathrm{H}$ ayat (1) UUD 1945 yang berbunyi setiap orang berhak hidup sejahtera lahir dan batin, bertempat tinggal dan mendapat lingkungan hidup yang baik dan sehat serta berhak memperoleh pelayanan kesehatan. Oleh karenanya menjadi kewajiban pemerintah untuk memenuhi hak asasi manusia tersebut sebagaimana tertera dalam Pasal 34 ayat (3) UUD 1945 yang berbunyi negara bertanggung jawab atas penyediaan fasilitas pelayanan kesehatan dan fasilitas pelayanan umum yang layak. Aspek

https://banten.antaranews.com/berita/25590/pertumbuhanekonomi-banten-lebih-tinggi-dari-nasional, diakses 15 September 2017.

$10 \quad$ Ibid. 


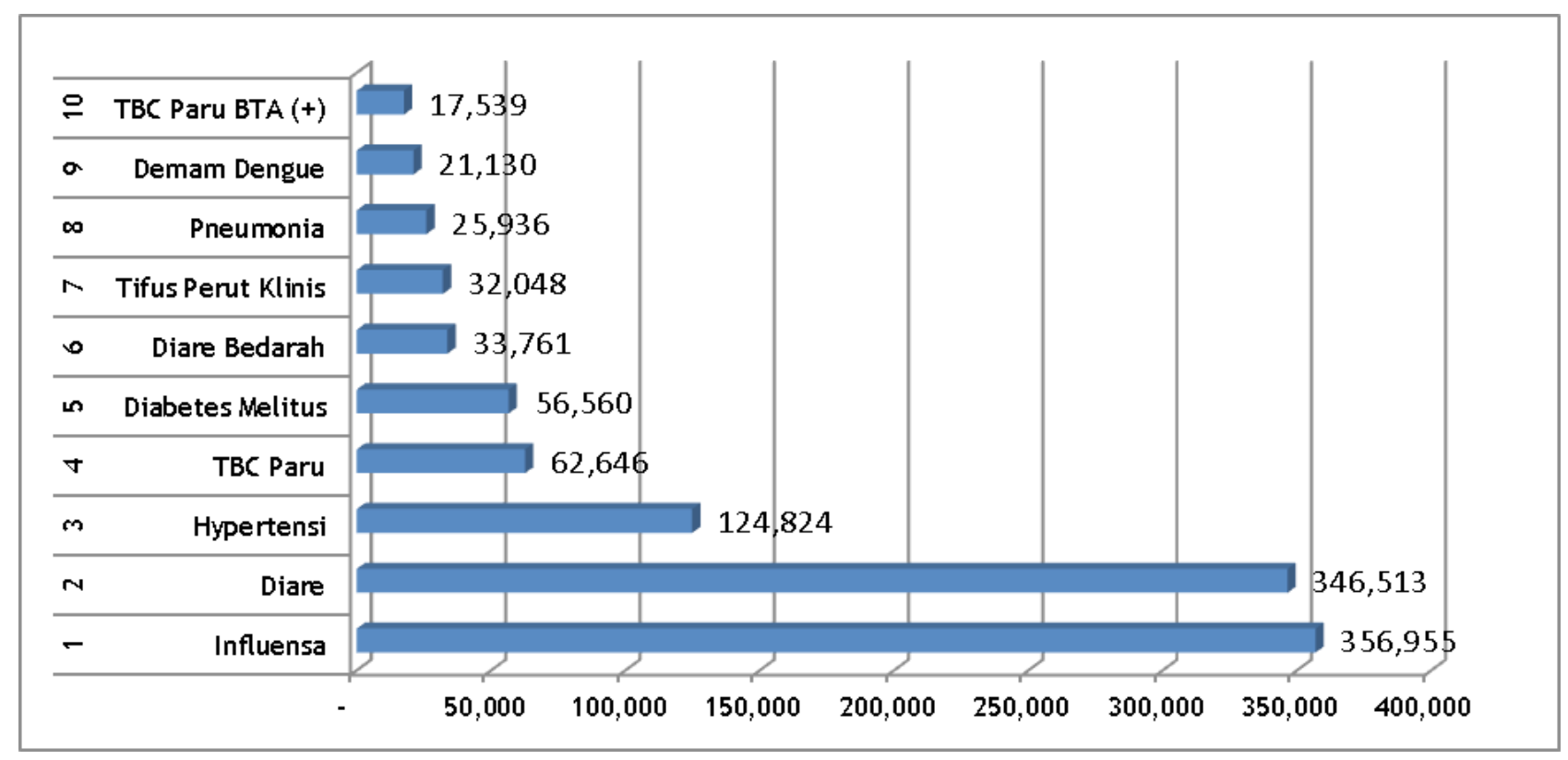

Grafik 1. Gambaran Penyakit di Provinsi Banten

Sumber data :Profil Kesehatan Provinsi Banten Tahun 2014.

kesehatan mempunyai pengaruh penting pada pembangunan nasional suatu bangsa.

Pembangunan kesehatan pada hakekatnya adalah upaya yang dilaksanakan oleh semua komponen Bangsa Indonesia yang bertujuan untuk meningkatkan kesadaran, kemauan, dan kemampuan hidup sehat bagi setiap orang agar terwujud derajat kesehatan masyarakat yang setinggi-tingginya sebagai investasi bagi pembangunan sumber daya manusia yang produktif secara sosial dan ekonomis. Sasaran pembangunan kesehatan pada tahun 2025 adalah meningkatnya umur harapan hidup, menurunnya Angka Kematian Bayi (AKB) dan Angka Kematian Ibu (AKI) serta menurunnya prevalensi gizi kurang pada balita. AKB dan AKI merupakan ukuran mortalitas atau tingkat kematian yang sering digunakan untuk mengevaluasi upaya pembangunan kesehatan yang telah dilakukan pemerintah. Derajat kesehatan masyarakat digambarkan melalui angka kematian (mortalitas), angka kesakitan (morbiditas) dan status gizi balita.

AKB merupakan jumlah bayi yang meninggal sebelum mencapai usia satu tahun yang dinyatakan dalam 1.000 kelahiran hidup pada tahun yang sama. Tahun 2013 AKB Provinsi Banten adalah 5,8 per 1.000 kelahiran hidup. Angka ini meningkat dari tahun 2011 di mana AKB mencapai 5,2 per 1.000 kelahiran hidup. Penurunan AKB ini banyak dipengaruhi kegiatan pelatihan manajemen supervisor pada kasus asfiksia (kekurangan oksigen) dan kasus Berat Badan Lahir Rendah (BBLR); kemitraan bidan dengan dukun; persalinan oleh tenaga kesehatan; Program Perencanaan Persalinan dan Pencegahan Kehamilan (P4K); dan asuhan kebidanan dari masa maternal hingga perinatal.

Selain AKB, indikator mortalitas yang digunakan di Provinsi Banten juga berupa AKI. AKI merupakan indikator penting dalam menggambarkan derajat kesehatan masyarakat. AKI menggambarkan jumlah wanita yang meninggal dari suatu penyebab kematian terkait dengan gangguan kehamilan atau dari suatu penyebab kematian terkait dengan gangguan kehamilan atau penanganannya (tidak termasuk kecelakaan atau kasus insidental) selama kehamilan, melahirkan dan dalam masa nifas (42 hari setelah melahirkan) tanpa memperhitungkan lama kehamilan per 100.000 kelahiran hidup. AKI juga dapat digunakan dalam pemantauan kematian terkait dengan kehamilan. Indikator ini dipengaruhi status kesehatan secara umum, pendidikan, dan pelayanan selama kehamilan dan melahirkan. Sensitivitas AKI terhadap perbaikan pelayanan kesehatan 
menjadikannya indikator keberhasilan pembangunan sektor kesehatan.

AKI di Provinsi Banten pada tahun 2013 sebesar 359,1 per 100.000 kelahiran hidup. Angka ini meningkat jika dibandingkan dengan AKI di tahun 2011 yang mencapai 79,5 per 100.000 kelahiran hidup. Penurunan AKI ini dipengaruhi oleh program antenatal care terpadu, pemantapan kelas ibu hamil, pembinaan kemitraan bidan dengan dukun, persalinan oleh tenaga kesehatan, dan pelayanan kesehatan ibu lainnya.

Morbiditas juga berperan dalam penilaian terhadap derajat kesehatan masyarakat di suatu wilayah dalam periode waktu tertentu. Morbiditas menggambarkan kejadian penyakit yang terjadi di masyarakat baik yang dilaporkan oleh fasilitas pelayanan kesehatan melalui surveilans rutin maupun dari adanya laporan KLB atau wabah. Morbiditas penyakit menular yang banyak menginfeksi masyarakat di Provinsi Banten dinyatakan dalam angka insiden maupun angka prevalens.

Dari tabel tersebut terlihat bahwa penyakit yang paling banyak terjadi pada masyarakat Banten adalah influenza, diare, dan hipertensi. Influenza menduduki peringkat pertama penyakit terbanyak di masyarakat pada tahun 2013 yaitu sebanyak 356.955 kasus, selanjutnya diikuti oleh penyakit diare sebanyak 346.513 kasus, hipertensi sebanyak 124.824 kasus, TB paru sebanyak 62.646 kasus, diabetes melitus sebanyak 56.560 kasus, diare berdarah sebanyak 33.761 kasus, tifus klinis sebanyak 32.048 kasus, pneumonia sebanyak 25.936 kasus, demam berdarah dengue sebanyak 21.130 kasus dan TB paru BTA (+) 17.539 kasus.

\section{Derajat Kesehatan Lingkungan}

Salah satu faktor yang memengaruhi kesehatan masyarakat adalah kualitas lingkungan. Hal ini sesuai dengan teori belum yang menyatakan bahwa derajat kesehatan masyarakat dipengaruhi oleh determinan yang saling berkaitan satu sama lain yaitu determinan lingkungan, perilaku kesehatan, genetik dan akses fasilitas pelayanan kesehatan. Namun kualitas lingkungan hidup semakin lama semakin menurun sebagai dampak dari adanya pembangunan dan perkembangan era globalisasi. Dampak tersebut sebagai ancaman tradisional yang sejak dahulu erat berhubungan dengan faktor kemiskinan dan keterbelakangan pembangunan yang meliputi keterbatasan persediaan air minum yang aman, keterbatasan persediaan fasilitas sanitasi dasar di rumah dan lingkungan masyarakat, adanya polusi udara yang berasal dari dalam rumah dan kurangnya fasilitas pembuangan sampah. Di samping itu, juga adanya ancaman modern yang mencakup polusi air dari industri dan pertanian intensif, polusi udara perkotaan dari kendaraan bermotor, tenaga batu bara dan industri, perubahan cuaca, penipisan lapisan ozon stratosfir dan polusi lintas batas (Supraptini dan Tin Afifah. 2006). Untuk menggambarkan keadaan lingkungan di Provinsi Banten, digunakan indikator seperti akses terhadap air bersih dan air minum berkualitas dan akses terhadap sanitasi layak.

Tahun 2011 kepala keluarga yang mempunyai air bersih sebanyak 1.039.796. Jumlah tersebut naik pada tahun 2013 yaitu mencapai 1.243 .157 kepala keluarga. Dari jumlah tersebut, kepala keluarga yang menggunakan ledeng sebanyak 203.358 $(16.4 \%)$, sumur pompa tangan sebanyak 123.494 (9.9\%), sumur gali sebanyak 314.802 (25.3\%), penampungan air hujan sebanyak $5.832(0.5 \%)$, penggunaan air kemasan $9.678(0.8 \%)$ dan lainnya sebanyak 533.316 (42.9\%). Sedangkan pada tahun 2011, kepala keluarga yang menggunakan ledeng sebanyak $236.426(22,7 \%)$, sumur pompa tangan sebanyak $192.605(18,5 \%)$, sumur gali sebanyak $312.734 \quad(30,1 \%)$, penampungan air hujan sebanyak 9.583 $(0,9 \%)$, air kemasan sebanyak $11.353(1,1 \%)$ dan lainnya sebanyak $412.406 \quad(39,7 \%)$. 
Dengan pemakaian sumber air bersih yang sesuai dengan syarat kesehatan diharapkan penularan penyakit dapat diminimalisir bila masyarakat melaksanakan PHBS.

Untuk mencegah atau mengurangi kontaminasi tinja terhadap lingkungan maka pembuangan tinja harus dikelola dengan baik seperti pembuangan tinja harus di suatu tempat tertentu atau jamban sehat. Pembuangan tinja layak adalah dengan menggunakan jamban sendiri atau bersama serta menggunakan jamban leher angsa. Sementara tempat pembuangan akhir tinja berupa tangki septi atau saluran pembuangan air limbah.

Pada tahun 2013, jumlah kepala keluarga yang diperiksa kepemilikan jambannya mencapai 1.003.364. Dari jumlah tersebut yang menggunakan jamban sehat sebanyak 568.452 (70.5\%). Proporsi kepala keluarga yang memiliki jamban pada tahun 2013 tersebut meningkat jika dibandingkan dengan tahun 2011. Pada tahun 2011, jumlah kepala keluarga yang diperiksa kepemilikan jambannya mencapai 941.196. Dari jumlah tersebut, ada sebanyak $508.849(45,6 \%)$ yang menggunakan jamban sehat.

Tahun 2013, rumah di Provinsi Banten ada sebanyak 2.371.217. Dari jumlah tersebut, rumah yang diperiksa sebanyak 866.555 rumah (36.5\%). Terdapat sebanyak 510.678 rumah sehat $(56.0 \%)$. Jumlah tersebut meningkat jika dibanding tahun 2011. Pada tahun 2011, terdapat 2.253.718 rumah di Provinsi Banten. Dari jumlah tersebut, rumah yang diperiksa apakah memenuhi persyaratan sehat atau tidak ada sebanyak 1.048.120 rumah (46.5\%). Dari hasil pemeriksaan tersebut, diketahui rumah sehat di Provinsi Banten pada tahun 2011 sebanyak 587.316 rumah $(56.0 \%)$.

Program terpadu untuk mengetahui perilaku masyarakat tentang kesehatan adalah program PHBS. Pada tahun 2013 jumlah keseluruhan di 8 Kabupaten/Kota yang telah melaksanakan pembinaan berPHBS adalah sebanyak 1.131.243 rumah tangga. Dari jumlah tersebut yang berhasil menerapkan PHBS sebanyak 501.218. Pada tahun 2011, pemantauan rumah tangga PHBS mencapai 973.191 rumah tangga. Secara umum keadaan pada tahun 2013 menurun bila dibandingkan dengan tahun 2011. Di mana pada tahun 2011 jumlah rumah tangga Ber-PHBS mencapai 51\% sedangkan tahun 2013 mencapai 44,3\%.

\section{Keanekaragaman Hayati}

Keanekaragaman hayati di Indonesia terkonsentrasi di hutan alam, baik yang berada di pegunungan, rawa, dataran rendah, maupun di kawasan pantai. Provinsi Banten adalah salah satu provinsi di Pulau Jawa yang mempunyai potensi hutan alam yang luas dan kaya akan keanekaragaman hayati. Berdasarkan SK Menhut No 419/ Kpts-II/1999 tanggal 15 Juni 1999 tentang Penunjukkan Kawasan Hutan dan Perairan Provinsi Jawa Barat serta SK Penunjukkan Parsial. Luas kawasan hutan dan perairan yang dimiliki Provinsi Banten mencapai \pm 253.218,27 ha, dan luas daratan kawasan hutannya mencapai 208.161,27 ha. Kawasan hutan tersebut meliputi hutan konservasi, hutan lindung, dan hutan produksi.

Berdasarkan fungsinya, luas kawasan hutan (daratan) di Provinsi Banten terdiri dari: hutan konservasi (127.892,30 ha), hutan lindung (9.471,39 ha) dan hutan produksi $(70.797,58$ ha). Sedangkan kawasan konservasi di Provinsi Banten terdiri dari: Cagar Alam Gunung Tukung Gede, Cagar Alam Pulau Dua, Cagar Alam Rawa Danau, Taman Wisata Alam Pulau Sangiang, dan Taman Nasional Ujung Kulon.

Eksistensi keanekaragaman hayati di Provinsi Banten tidak hanya terancam oleh adanya kebijakan pemerintah daerah dalam pengembangan sektor jasa dan industri, tetapi juga oleh adanya kegiatan eksploitasi sumber daya hutan yang ada. Kegiatan eksploitasi SDA tidak hanya mengancam keanekaragaman hayati, tetapi juga telah merusak fungsi hutan dalam menjaga tata air, sehingga ketika musim hujan tiba kawasankawasan permukiman, persawahan, dan tata 
guna lahan lainnya di hilir Daerah Aliran Sungai (DAS) tergenang air. Sementara ketika musim kemarau, terjadi kelangkaan air di kawasan yang sangat luas, yang tidak saja menyulitkan masyarakat untuk memenuhi kebutuhan air bersih, tetapi juga berdampak pada sektor pertanian karena debit air saluran irigasi sangat rendah atau kering (Wawancara dengan Staf BKSDA Jawa Barat Kantor Wilayah Banten).

Demikian juga pengembangan industri di wilayah utara Provinsi Banten, pengelolaan yang tidak dilakukan dengan baik telah mengganggu dan merusak ekosistem laut. Kondisi ini mengakibatkan ikan sulit dicari sehingga tangkapan ikan para nelayan juga cenderung menurun. Skala dan intensitas kegiatan di wilayah pesisir dan laut Teluk Banten meningkat dengan cepat seiring dengan perkembangan kependudukan dan perekonomian. Proses-proses ini berpotensi menyebabkan terjadinya perubahan ekosistem teluk dan berdampak besar bagi masyarakat terutama yang menggantungkan hidupnya pada sumber daya pesisir dan laut. ${ }^{11}$

Rusaknya lingkungan dan terjadinya kepunahan keanekaragaman hayati di Provinsi Banten tidak hanya karena perkembangan kependudukan dan perekonomian. Tetapi juga karena peran masyarakat (Wawancara dengan Staf BKSDA Jawa Barat Kantor Wilayah Banten), seperti:

a. perambahan di kawasan Cagar Alam Rawa Danau sehingga mengancam eksistensi Rawa Danau sebagai kawasan rawa pegunungan satu-satunya di Pulau Jawa dan ekosistem rawa yang ada di dalamnya;

b. perambahan di Taman Nasional Ujung Kulon dan pembantaian badak untuk diambil culanya;

c. penjarahan burung di Cagar Alam Pulau Dua;

d. Penebangan hutan di kawasan-kawasan lindung dan cagar alam;

e. Penebangan bakau untuk dijadikan kawasan tambak di hampir sepanjang pantai utara,

\footnotetext{
11 "Pendahuluan," http://repository.ipb.ac.id/jspui/ bitstream/123456789/40870/2/BAB\%20I_2007sja-2.pdf, diakses 2 Februari 2018.
}

mulai dari Teluk Naga Tangerang sampai dengan Sawah Luhur, Serang;

f. Pengambilan terumbu karang;

g. pengambilan ikan dengan menggunakan bom dan sianida, yang mengancam dan membunuh terumbu karang;

h. penggunaan alat tangkap ikan yang tidak ramah lingkungan, seperti dengan menggunakan pukat harimau, arad, gardan, dan lain sebagainya.

Seksi Konservasi Wilayah I (Wilayah Serang) Balai Besar KSDA Jawa Barat mencatat ada beberapa hewan dan tumbuhan yang terancam punah di Provinsi Banten, yaitu: Badak Bercula Satu (Rhinoceros sondaicus), Surili (Presbytis comata), Macan tutul (Panthera pardus melas), Burung pantai Bintayung (Fregata andrewsi), dan Kokoleceran (Vatica bantamensis).

Menghadapi kondisi tersebut, beberapa upaya telah dilakukan oleh Seksi Konservasi Wilayah I Banten BBKSDA Jawa Barat dalam upaya mempertahankan keanekaragaman hayati, yaitu dengan melakukan:

a. pembinaan habitat di Pulau Sangiang;

b. pengamanan dan penjagaan kawasan konservasi, seperti melalui kegiatan patroli, operasi pengamanan;

c. penyuluhan konservasi ke tokoh masyarakat, masyarakat dan ke sekolah;

d. pembinaan kader konservasi, kelompok pecinta alam (Wawancara dengan Staf BKSDA Jawa Barat Kantor Wilayah Banten).

Tantangan yang dihadapi oleh Seksi Konservasi Wilayah I Banten BBKSDA Jawa Barat dalam melaksanakan berbagai upaya tersebut antara lain: perambahan yang dilakukan oleh masyarakat, jumlah sumber daya manusia yang dimiliki kurang. Di Seksi Konservasi Wilayah I Banten BBKSDA Jawa Barat hanya ada 16 PNS Polhut, TPHL, PEH, dan PPNS dengan luas kawasan konservasi mencapai 6.343.20 ha dan keterbatasan anggaran. 


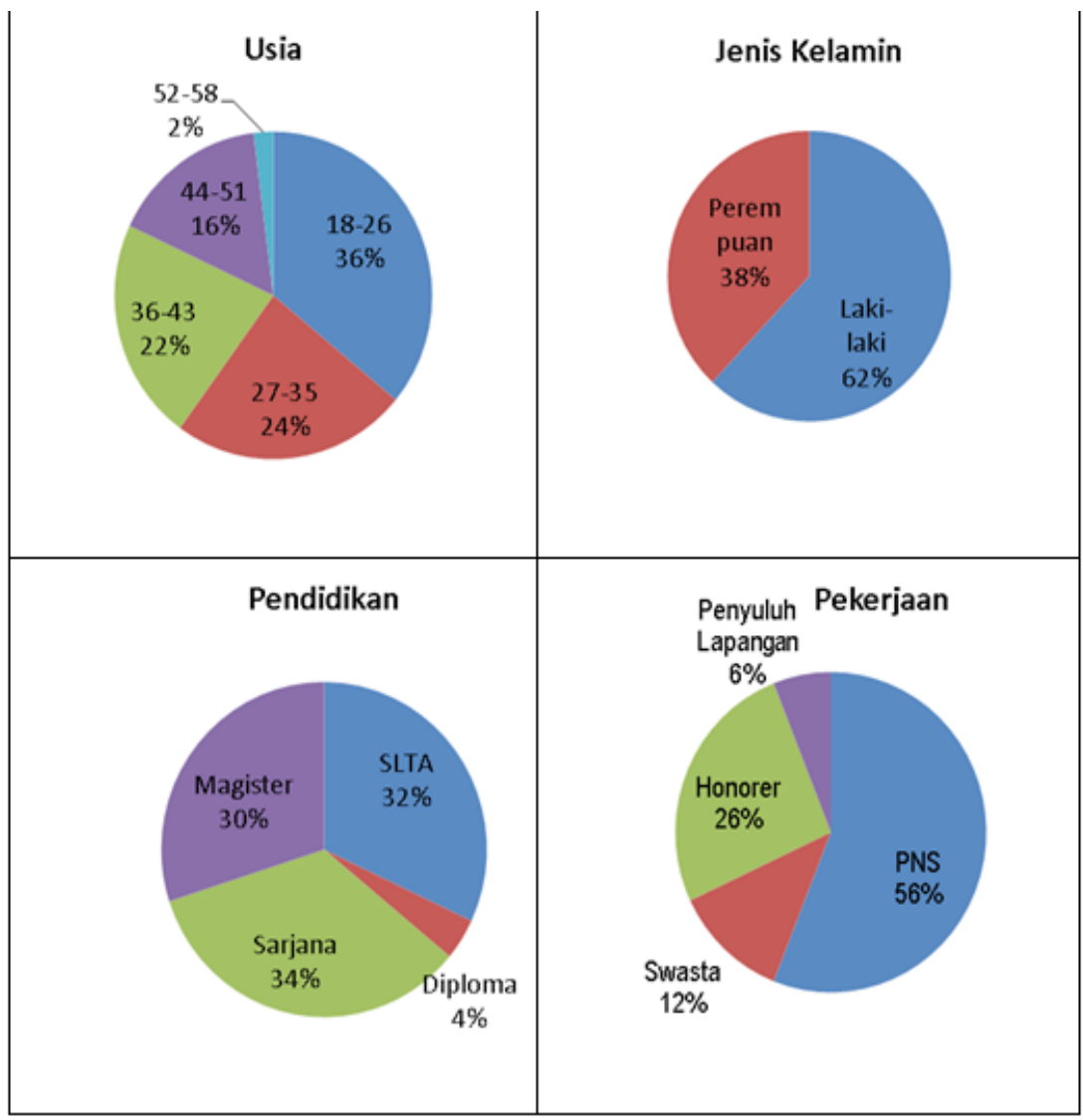

Grafik 2. Gambaran Responden

Hubungan antara IKLH dengan Pemenuhan Kebutuhan Dasar

\section{Gambaran Responden}

Jumlah responden sebanyak 50 orang, dengan gambaran responden sebagaimana Grafik 2.

Jumlah responden adalah 50 orang, sebagian besar berada pada usia 18-26 tahun. Terdiri dari 62\% laki-laki dan 38\% perempuan.
Adapun pendidikan responden sebagian besar sarjana, disusul kemudian SLTA dan kemudian magister dalam jumlah yang tidak jauh berbeda. Jenis pekerjaan responden sebagian besar PNS $(50 \%)$

\section{Persepsi Responden}

Persepsi responden terkait kondisi

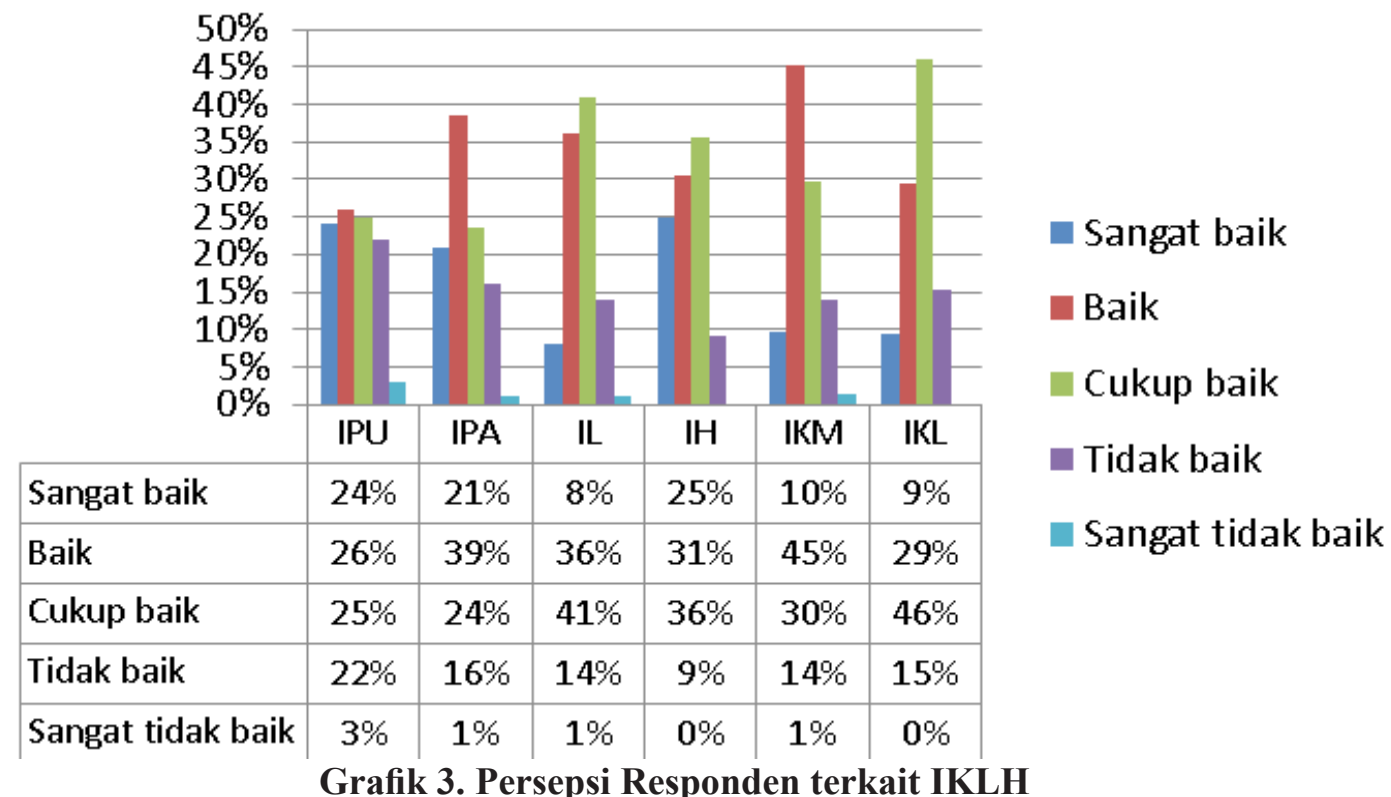




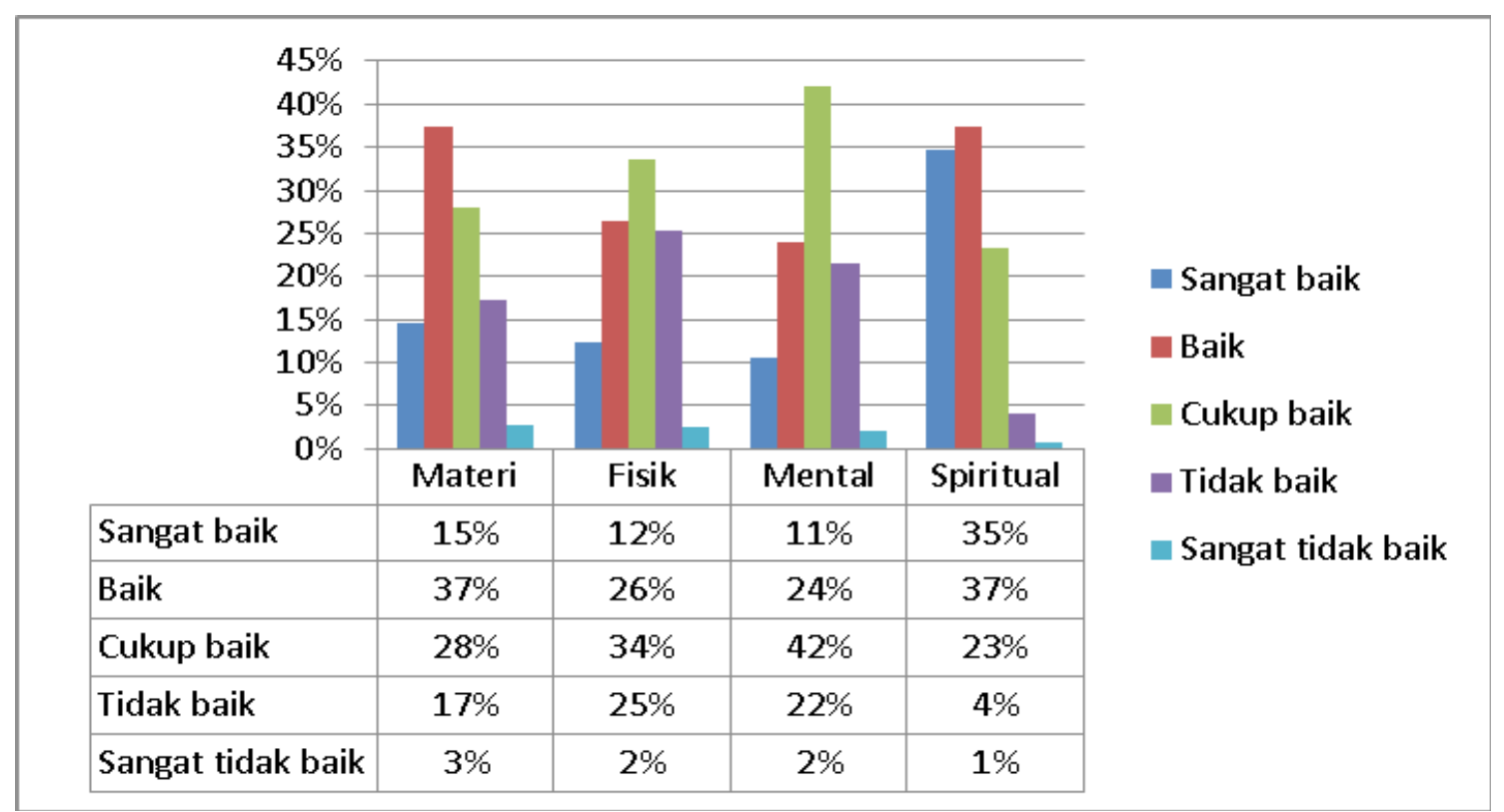

Grafik 4. Persepsi Responden terkait IKLH

lingkungan di Provinsi Banten rata-rata baik dan cukup baik. Mayoritas responden berpendapat baik untuk indeks kualitas udara, kualitas air dan kesehatan masyarakat. Sedangkan indeks tutupan lahan, keanekaragaman hayati dan kesehatan lingkungan dipersepsikan cukup baik oleh responden.

Walaupun mayoritas responden menjawab seperti di atas, namun yang patut dicermati dari grafik tersebut adalah masih adanya responden yang berpendapat bahwa indeks lingkungan tidak baik, kisarannya sekirar 9\% s.d. $22 \%$. Hal ini patut menjadi perhatian karena dapat diasumsikan kondisi kualitas lingkungan belum merata dirasakan oleh masyarakat Banten. Hal ini diindikasikan oleh disparitas jawaban responden mulai dari sangat baik, baik, cukup baik, tidak baik, bahkan sangat tidak baik untuk beberapa indikator.

Adapun persepsi responden terkait pemenuhan kebutuhan dasar dapat dilihat pada Grafik berikut. Sebagian besar responden berpendapat bahwa pemenuhan kebutuhan dasar di Provinsi Banten adalah baik dan cukup baik. Mayoritas responden berpendapat baik untuk pemenuhan materi dan spiritual, dan cukup baik pada fisik dan mental. Hal ini dapat diasumsikan bahwa mayoritas responden sudah terpenuhi kebutuhan material dan spiritual, Keseimbangan antara material dan spiritual diharapkan menjadi modal dasar dalam pembangunan manusia.

\section{Hasil Uji Korelasi}

Tabel 3. Hasil Uji Korelasi Antara Variabel X dengan Variabel $Y$

\begin{tabular}{|c|c|c|c|}
\hline \multicolumn{4}{|c|}{ Correlations } \\
\hline & & IKLH & KebDasar \\
\hline \multirow{3}{*}{ IKLH } & Pearson & 1 & $.610^{* *}$ \\
\hline & $\begin{array}{l}\text { Correlation } \\
\text { Sig. (2-tailed) }\end{array}$ & & .000 \\
\hline & $\mathrm{N}$ & 50 & 50 \\
\hline \multirow{3}{*}{ KebDasar } & Pearson & $.610^{* *}$ & 1 \\
\hline & $\begin{array}{l}\text { Correlation } \\
\text { Sig. (2-tailed) }\end{array}$ & .000 & \\
\hline & $\mathrm{N}$ & 50 & 50 \\
\hline
\end{tabular}

Berdasarkan tabel tersebut diketahui bahwa nilai signifikansinya $<0.05$, yang berarti terdapat korelasi yang signifikan antara gabungan masing-masing dimensi pada variabel kualitas lingkungan dengan variabel pemenuhan kebutuhan dasar. Nilai pearson correlation yang dihubungkan antar masingmasing variabel adalah sebesar 0.610** dan mempunyai tanda bintang. Nilai ini menujukkan bahwa terdapat korelasi yang kuat dan signifikan antar berbagai dimensi pada variabel $\mathrm{X}$ dengan variabel $\mathrm{Y}$.

Selanjutnya dilakukan pula uji korelasi antara masing-masing dimensi pada Variabel $\mathrm{X}$ dengan variabel $\mathrm{Y}$, maka didapatkan hasil 
Tabel 4. Korelasi antara Beberapa Dimensi pada Kualitas Lingkungan dengan Pemenuhan Kebutuhan Dasar

\begin{tabular}{llllll}
\hline No & Dimensi Var. $\mathbf{X}$ & Var. $\mathbf{Y}$ & Signifikansi & Pearson Correlation & Keterangan \\
\hline 1 & Pencemaran udara & Total seluruh & 0.00 & $0.566^{* *}$ & Berkorelasi kuat \\
2 & Kualitas air & dimensi pada & 0.001 & $0.469^{*}$ & Berkorelasi \\
3 & Tutupan lahan & $\begin{array}{l}\text { variabel } \\
\text { pemenuhan }\end{array}$ & 0.001 & $0.456^{*}$ & Berkorelasi \\
4 & Keanekaragaman & $\begin{array}{l}\text { kebutuhan } \\
\text { hayati }\end{array}$ & 0.141 & 0.211 & Tidak berkorelasi \\
5 & Kesehatan masyarakat & & 0.005 & $0.395^{*}$ & Berkorelasi \\
6 & Kesehatan lingkungan & & 0.00 & $0.487^{*}$ & Berkorelasi \\
\hline
\end{tabular}

sebagai berikut: (output hasil pengolahan data SPSS secara lengkap dapat dilihat pada Lampiran C):

Berdasarkan hasil perhitungan statistik tersebut terlihat bahwa semua indeks kualitas lingkungan berkorelasi dengan pemenuhan kebutuhandasar,kecualiindekskeanekaragaman hayati. Hal ini dapat dimungkinkan karena kurang tersosialisasikannya keanekaragaman hayati pada masyarakat, sehingga responden tidak memandang bahwa keanekaragaman hayati tersebut berhubungan dengan pemenuhan kebutuhan dasar. Provinsi Banten mempunyai cagar alam yang cukup luas di beberapa tempat, namun nampaknya belum dianggap suatu hal yang mendesak untuk diperhatikan oleh responden.

\section{Hasil Uji Regresi}

Hasil uji regressi terhadap kuesioner di Provinsi Banten adalah sebagai berikut:

Berdasarkan Tabel 5, nilai $\mathrm{R}$ yang merupakan nilai koefisien korelasi adalah sebesar 0.666. Nilai ini dapat diinterpretasikan bahwa hubungan kedua variabel penelitian ada di kategori cukup kuat. Nilai Koefisien Determinasi (KD) adalah sebesar 0,444 yang menunjuk bahwa variabel bebas $\mathrm{X}$ memiliki pengaruh kontribusi sebesar $44,4 \%$ terhadap variabel Y. Sisanya, sebesar 55,6\% dipengaruhi oleh faktor-faktor lain diluar dimensi-dimensi pada variabel $X$.

Selanjutnya adalah menentukan taraf signifikansi atau linieritas dari regresi. Kriterianya dapat ditentukan berdasarkan uji F atau uji nilai Signifikansi (Sig). Berdasarkan tabel di atas, nilai signifikansi penelitian ini adalah sebesar 0.002. Apabila Sig $<0.05$ maka model regresi adalah linier. Dengan demikian model persamaan regresi berdasarkan data penelitian adalah signifikan dan memenuhi kriteria linieritas. Dengan nilai F sebesar 5,715 dan Ho ditolak, maka dapat dikatakan bahwa terdapat hubungan antara dimensi-dimensi pada kualitas lingkungan dengan pemenuhan dasar. Adapan model persamaan regresinya adalah sebagai berikut:

$$
\begin{gathered}
Y=13,286+1,703 X_{1}+0,323 X_{2}+1,083 X_{3}+ \\
0,111 X_{4}+0,204 X_{5}+0,828 X_{6}
\end{gathered}
$$

Di mana:

$\mathrm{X}_{1}=$ Kualitas udara $\quad \mathrm{X}_{4}=$ Keanekaragaman hayati $\mathrm{X}_{2}=$ Kualitas air $\quad \mathrm{X}_{5}=$ Kesehatan masyarakat $\mathrm{X}_{3}=$ Tutupan lahan $\quad \mathrm{X}_{6}=$ Kesehatan lingkungan

Berdasarkan persamaan di atas, semua dimensi pada variabel $\mathrm{X}$ bernilai positif. Hal ini berarti, apabila terjadi kenaikan kualitas udara, kualitas air, tutupan lahan, keanekaragaman hayati, kesehatan masyarakat dan kesehatan lingkungan maka pemenuhan kebutuhan dasar akan meningkat, begitu juga sebaliknya.

Kualitas udara dan tutupan lahan mempunyai konstanta yang paling besar diantara indeks lainnya. Dengan demikian, kenaikan dari nilai tersebut akan berdampak lebih besar pada kenaikan pemenuhan dasar, demikian juga sebaliknya. Oleh karena itu, udara yang bersih dan tutupan lahan yang luas dianggap responden paling berpengaruh terhadap pemenuhan kebutuhan dasarnya.

Selanjutnya dilakukan uji regresi antara IKLH dengan pemenuhan kebutuhan dasar di 
Tabel 5. Hasil Uji Regresi

Model Summary

\begin{tabular}{|c|c|c|c|c|c|c|}
\hline Model & $\mathbf{R}$ & R Square & Adjusted R Square & \multicolumn{3}{|c|}{ Std. Error of the Estimate } \\
\hline 1 & $.666^{\mathrm{a}}$ & .444 & .366 & \multicolumn{2}{|l|}{7.06520} & \\
\hline \multicolumn{7}{|c|}{ a. Predictors: (Constant), IKL, IH, IPU, IKM, IPA, IL } \\
\hline \multicolumn{7}{|c|}{ ANOVA $^{a}$} \\
\hline & Model & Sum of Squares & df & Mean Square & $\mathbf{F}$ & Sig. \\
\hline 1 & $\begin{array}{l}\text { Regression } \\
\text { Residual } \\
\text { Total } \\
\end{array}$ & $\begin{array}{l}1711.570 \\
2146.430 \\
3858.000 \\
\end{array}$ & $\begin{array}{l}6 \\
43 \\
49 \\
\end{array}$ & $\begin{array}{l}285.262 \\
49.917\end{array}$ & 5.715 & $.000^{\mathrm{b}}$ \\
\hline
\end{tabular}

a. Dependent Variable: KebDasar

b. Predictors: (Constant), IKL, IH, IPU, IKM, IPA, IL

Coefficients $^{\text {a }}$

\begin{tabular}{|c|c|c|c|c|c|c|}
\hline & \multirow{2}{*}{ Model } & \multicolumn{2}{|c|}{ Unstandardized Coefficients } & \multicolumn{2}{|c|}{ Standardized Coefficients } & \multirow[b]{2}{*}{ Sig. } \\
\hline & & $\overline{\mathbf{B}}$ & Std. Error & Beta & $\mathrm{T}$ & \\
\hline \multirow{7}{*}{1} & (Constant) & 13.286 & 8.172 & & 1.626 & .111 \\
\hline & IPU & 1.703 & .779 & .326 & 2.185 & .034 \\
\hline & IPA & .323 & .486 & .098 & .665 & .510 \\
\hline & IL & 1.083 & 1.036 & .167 & 1.045 & .302 \\
\hline & $\mathrm{IH}$ & .111 & .484 & .033 & .230 & .819 \\
\hline & IKM & .204 & .330 & .089 & .618 & .540 \\
\hline & IKL & .828 & .638 & .194 & 1.297 & .201 \\
\hline
\end{tabular}

a. Dependent Variable: KebDasar

Provinsi Banten dengan hasil sebagaimana $\mathrm{X}$ dan $\mathrm{Y}$ adalah sebesar 0.00 dengan nilai $\mathrm{F}$ Tabel 6. Nilai $R$ adalah sebesar 0.0 yang sebesar 28,393, hal ini menunjukkan bahwa berarti masih ada hubungan yang cukup kuat model regresi ini signifikan dan terdapat antara dua variabel ini. Berdasarkan koefisien hubungan antara kualitas lingkungan dengan determinasi, hanya sebesar $37 \%$ vaiabel kebutuhan dasar dengan model persamaan kualitas lingkungan berpengaruh terhadap regresi sebagai berikut:

pemenuhan kebutuhan dasar. Sisanya sebesar $63 \%$ dipengaruhi oleh faktor-faktor lain di luar variabel kualitas lingkungan.

Tabel 6. Hasil Uji Regresi

\begin{tabular}{cllll}
\hline \multicolumn{5}{c}{ Model Summary } \\
\hline Model & $\mathbf{R}$ & R Square & Adjusted R Square & Std. Error of the Estimate \\
\hline 1 & $.610^{\text {a }}$ & .372 & .359 & 7.10647 \\
a. Predictors: (Constant), IKLH & & \\
\hline
\end{tabular}

Signifikansi dari hubungan antara variabel

\begin{tabular}{lllllll}
\hline Model & & Sum of Squares & df & Mean Square & F & Sig. \\
\hline \multirow{2}{*}{1} & Regression & 1433.910 & 1 & 1433.910 & 28.393 & $.000^{\mathrm{b}}$ \\
& Residual & 2424.090 & 48 & 50.502 & & \\
& Total & 3858.000 & 49 & & & \\
\hline
\end{tabular}

a. Dependent Variable: KebDasar

b. Predictors: (Constant), IKLH

Coefficients $^{\mathrm{a}}$

\begin{tabular}{|c|c|c|c|c|c|c|}
\hline & \multirow{2}{*}{ Model } & \multicolumn{2}{|c|}{ Unstandardized Coefficients } & Standardized Coefficients & & \multirow[b]{2}{*}{ Sig. } \\
\hline & & $\mathrm{B}$ & Std. Error & Beta & $\mathrm{T}$ & \\
\hline \multirow{2}{*}{1} & (Constant) & 10.299 & 7.741 & & 1.330 & .190 \\
\hline & IKLH & .554 & .104 & .610 & 5.329 & .000 \\
\hline
\end{tabular}

a. Dependent Variable: KebDasar 


$$
Y=0,554, X+10,229
$$

Hal ini berarti setiap kenaikan sekitar setengah kali kualitas lingkungan akan menaikkan satu kali pemenuhan kebutuhan dasar. Dengan demikian apabila kebutuhan dasar masyarakat ingin dipenuhi sebesar satu tingkat, maka kualitas lingkungan perlu untuk ditingkatkan sebanyak setengah tingkat. Untuk memenuhi kebutuhan dasar masyarakatyang terdiri dari kebutuhan materi, fisik, mental dan spiritual, maka pemerintah perlu meningkatkan kualitas lingkungan yang terdiri dari kualitas udara, kualitas udara, tutupan lahan, keanekaragaman hayati, kesehatan masyarakat dan kesehatan lingkungan dengan skala dua kali lipatnya. Hal ini tentu menjadi tantangan tersendiri bagi Pemerintah Banten dalam upaya memenuhi kebutuhan masyarakatnya sekaligus dalam upaya meningkatkan kesejahteraan secara merata bagi seluruh masyarakat Banten.

\section{Penutup \\ Simpulan}

Provinsi Banten memiliki pertumbuhan ekonomi yang cukup tinggi, demikian juga nilai investasinya. Namun beberapa permasalahan lingkungan kerap terjadi seperti pencemaran udara karena padatnya transportasi maupun pencemaran air yang dikarenakan limbah domestik dan industri baik yang berasal dari Provinsi Banten sendiri maupun dari provinsi sekitar.

Hasil penelitian menunjukkan bahwa persepsi responden terkait kondisi lingkungan di Provinsi Banten rata-rata baik dan cukup baik. Mayoritas responden berpendapat bahwa kualitas udara, kualitas air dan kesehatan masyarakat adalah baik, sedangkan tutupan lahan, keanekaragaman hayati, dan kesehatan lingkungan dipersepsikan cukup baik oleh responden.

Selanjutnya pemenuhan kebutuhan dasar di Provinsi Banten juga dianggap mayoritas responden baik dan cukup baik. Mayoritas responden berpendapat baik untuk pemenuhan materi dan spiritual, dan cukup baik pada fisik dan mental. Berdasarkan hasil perhitungan statistik, dapat disimpulkan bahwa semua indeks kualitas lingkungan berkorelasi dengan pemenuhan kebutuhan dasar, kecuali indeks keanekaragaman hayati. Hal ini dapat dimungkinkan karena kurang tersosialisasikannya keanekaragaman hayati pada masyarakat, sehingga responden tidak memandang bahwa keanekaragaman hayati tersebut berhubungan dengan pemenuhan kebutuhan dasar. Provinsi Banten mempunyai cagar alam yang cukup luas di beberapa tempat, namun nampaknya belum dianggap suatu hal yang mendesak untuk diperhatikan oleh responden.

Berdasarkan uji korelasi juga didapatkan bahwa semua indeks kualitas lingkungan berpengaruh positif terhadap pemenuhan kebutuhan dasar. Hal ini berarti, apabila terjadi kenaikan kualitas udara, kualitas air, tutupan lahan, keanekaragaman hayati, kesehatan masyarakat, dan kesehatan lingkungan maka pemenuhan kebutuhan dasar akan meningkat, begitu juga sebaliknya.

Indeks kualitas udara dan tutupan lahan mempunyai konstanta yang paling besar di antara indeks lainnya. Dengan demikian, kenaikan dari nilai tersebut akan berdampak lebih besar pada kenaikan pemenuhan dasar. Demikian juga sebaliknya, apabila indeks kualitas udara dan tutupan lahan mengalami penurunan, maka pemenuhan kebutuhan dasar masyarakat juga akan menurun.

\section{Saran}

Hasil telaah hubungan antara kualitas lingkungan dan pemenuhan kebutuhan dasar dapat menjadi masukan bagi pemerintah dan para pemegang keputusan dalam memenuhi kebutuhan dasar masyarakat sekaligus meningkatkan kualitas lingkungannya.

Kualitas udara dan tutupan lahan dianggap responden paling berpengaruh terhadap pemenuhan kebutuhan dasarnya. Oleh karena itu, program-progam untuk meningkatkan kualitas udara dan menjaga tutupan lahan 
menjadi prioritas yang perlu dilakukan di khususnya di kawasan perkotaan di samping tentunya terus berupaya menjaga dan meningkatkan kualitas perairan, kesehatan masyarakat, dan keanekaragaman hayati.

\section{UCAPAN TERIMA KASIH}

Ucapan terima kasih saya sampaikan ke beberapa pihak yang sudah turut berkontrusi dalam penelitian ini. Khususnya para peneliti Pusat Penelitian Badan Keahlian DPR RI yang telah bekerja sama melakukan penelitian kelompok tentang "Telaah terhadap Indikator Kesejahteraan Sosial dalam Bidang Lingkungan" yakni: Sri Nurhayati Qodriyatun, S.Sos., M.Si., Dr. Rohani Budi Prihatin, M.Si., Teddy Prasetiawan, ST., MT. dan Rahmi Yuningsih, S.K.M., M.K.M. Serta seluruh instansi terkait di Provinsi Banten, dan masyarakat Provinsi Banten yang menjadi responden penelitian ini.

\section{DAFTAR PUSTAKA}

\section{Jurnal}

Qodriyatun, S. N. (2016). Terabaikannya lingkungan hidup dalam pembangunan. Info Singkat, VIII(24), 9-12.

Supraptini \& Afifah, Tin. (2006). "Kondisi Kesehatan Lingkungan di Indonesia dan Angka Kematian Bayi, Angka Kematian Anak Balita serta Angka Kematian Balita menurut Data Susenas 1998. 2001 dan 2003" Jurnal Ekologi Kesehatan, Vol. 5 No. 3. Jakarta: Departemen Kesehatan. Hlm.453.

\section{Buku}

Achmadi, Umar Fahmi. (2013). Kesehatan Masyarakat: Teori dan Aplikasi. Jakarta: Rajawali Pers.

Fauzi, Ahmad dan Octavianus, Alex. (2013). Background Study RPJMN 2015 - 2019 Indeks Pembangunan Lingkungan Hidup. Jakarta: Bappenas.

Guilford, J. P. \& Fruchter, Benjamin. (1978). Fundamental Statistic in Psycology and Education (6 $\left.6^{\text {th }} . e d\right)$. New York: McGraw-Hill.
Hidayat, Rahmat (ed). (2016). Pembangunan Wilayah Pesisir Konsep dan Implementasinya dalam Berbagai Sektor. Jalarta: Pusat Penelitian Badan Keahlian DPR RI dan Dian Pustaka.

Kasiati, NS, Ni Wayan Dwi Rosmalawati. (2016). Kebutuhan Dasar Manusia I. Jakarta: Pusdik SDM Kesehatan Badan Pengembangan dan Pemberdayaan Sumber Daya Manusia Kesehatan.

Kumar, R. (1999). Research Methodology: A Step by Step Guide for Beginners. London: Sage Publication.

Kusnoputranto, Haryoto. (1986). Kesehatan Lingkungan. Jakarta: Depdikbud dan Fakultas Kesehatan Masyarakat Universitas Indonesia.

Mulyana, Deddy. (2004). Metodologi Penelitian Kualitatif. Bandung: PT Remaja Rosdakarya.

Notoatmodjo, Soekidjo. (2007). Kesehatan Masyarakat: Ilmu dan Seni. Jakarta: Rineka Cipta.

Palupi,Lutfi Kristiana.(2014). "Persepsi Masyarakat terhadap Pengelolaan Lingkungan Hidup di Kecamatan Ngampilan Kota Yogyakarta." Skripsi. Program Studi Pendidikan Geografi Fakultas Ilmu Sosial Universitas Negeri Yogyakarta.

Prasurya, Rizky Adi. (2016). "Analisis Pengaruh PDRB Terhadap Kualitas Lingkungan Hidup di Pulau Sumatera Tahun 2010-2014." Skripsi. Fakultas Ekonomi Dan Bisnis Universitas Lampung.

Soemirat, Juli. (2011). Kesehatan Lingkungan. Yogyakarta: Gadjah Mada University Press

Sudjana, Nana. (2004). Dasar-dasar Proses Belajar Mengajar. Bandung :Sinar Baru Algensido Offset.

Sugiyono. (2012). Metode Penelitian Kuantitatif Kualitatif dan $R \& D$. Bandung: Alfabeta.

Supranto, J. (1997). Pengukuran Tingkat Kepuasan Pelanggan. Jakarta: PT Rineka Cipta.

Suryani, Anih Sri. (2017). Pengaruh Kualitas Lingkungan terhadap Pemenuhan Kebutuhan Dasar Studi Persepsi Masyarakat di Provinsi Gorontalo. Bagian dari Buku "Indikator Kesejahteraan, Indikator Keberlanjutan Lingkungan Hidup dan Implementasinya di Indonesia Jakarta: Pusat Penelitian Badan Keahlian DPR RI dan Inteligensia Intrans Publishing. 
Syahrin, Alvi. tt. Pembangunan Berkelanjutan (Perkembangannya, Prinsip-Prinsip dan Status Hukumnya). Medan: Fakultas Hukum USU.

Zaman, Badrus dan Syafrudin. (2012). Buku Ajar Pengelolaan Kualitas Lingkungan. Semarang: Lembaga Pengembangan dan Penjaminan Mutu Pendidikan Universitas Diponegoro.

\section{Dokumen}

Bappenas. (2015). Capaian MDGS 2015.

Indeks Kualitas Lingkungan Hidup Indonesia. (2014). Kemeterian Lingkungan Hidup dan Kehutanan Republik Indonesia 2015.

Indeks Kualitas Lingkungan Hidup Indonesia. (2014). Kemeterian Lingkungan Hidup dan Kehutanan Republik Indonesia 2016.

Kementerian Kesehatan. (2013). Riset Kesehatan Dasar 2013.

Kemeterian Lingkungan Hidup dan Kehutanan Republik Indonesia. (2015). Indeks Kualitas Lingkungan Hidup Indonesia 2014.

Perpustakaan Bappenas. (2009). Indeks Kualitas Lingkungan Hidup.

Yuwono, Arief Sabdo. (2016). "Indikator Kualitas Lingkungan Hidup (IKLH) dan Kaitannya dengan Indikator Kesejahteraan Sosial ," Disampaikan dalam Diskusi tentang "Indikator Kesejahteraan Sosial Bidang Lingkungan," Bidang Kesejahteraan Sosial Pusat Penelitian BKD tanggal 7 Desember 2016.

Yuwono, Arief Sabdo. (2017). Disampaikan pada Focus Group Discussion Proposal Penelitan Kelompok Tentang "Telaah terhadap Indikator Kesejahteraan Sosial Bidang Lingkungan," Pusat Penelitian Badan Keahlian DPR RI, 20 Maret 2017.

\section{Intenet}

Bantaeng Menjadi Uji Coba Penanggulangan Kemiskinan di Indonesia, http://rakyatsulsel.com/107900. html, diakses 3 Maret 2017.

Definisi Kesehatan Masyarakat, https://www.academia.edu/8278738/ Definisi_Kesehatan_Masyarakat, diakses 3 Maret $201 \overline{7}$.
Hak atas Lingkungan yang Baik dan Sehat, http:// www.academia.edu/9614003/hak_atas_lingkungan_yang_baik_dan_sehat, diakses 2 Februari 2018.

Indeks Kebahagiaan Indonesia 2014 Sebesar 68,28 pada Skala 0-100, https://www.bps.go.id/ brs/ view/id/1117, diakses 20 Maret 2017.

Keanekaragaman Hayati Kondisi dan Permasalahannya, http://ani mardiastuti. staff. ipb.ac.id/files/2011/09/kehati-dan-permasalahannya.pdf, diakses 2 Maret 2017.

Modul I Keanekaragaman Hayati, http://file. upi.edu/direktori/FPMIPA/jur. pend. biologi/195305221980021-suroso_adi_yudianto/modul/modul1_keane karagaman hayaTI.pdf, diakses 2 Maret 2017.

PDRB Penduduk Bantaeng Naik 8,15 Persen, https:// bantaengkab.go.id/pdrb-penduduk-bantaengnaik-815-persen/, diakses 3 maret 2017.

Pendahuluan, http://repository.ipb.ac.id/ jspui/ bitstream/123456789/40870/2/BAB\%20 I_2007sja-2.pdf, diakses 2 Februari 2018.

Pengertian Kesehatan Masyarakat, http://www.indonesian-publichealth.com/ pengertian-kesehatan-masyarakat-2/, diakses 2 Maret 2017.

Pengertian Kesehatan Mental, http://www.alodokter. com/kesehatan-mental, diakses 29 Maret 2017. "Definisi Kesehatan Masyarakat," https://www. academia.edu/8278738/ Definisi_Kesehatan Masyarakat, diakses 3 Maret 2017.

Perbandingan PDRB Kabupaten/Kota 2010, https:// bpspenajampaserutara. wordpress.com/category/pendapatan-regional/, diakses 3 Maret 2017.

Sekelumit tentang Social Progress Index, https:// www.academia.edu/ 10443993/Sekelumit tentang_Social_Progress_Index, diakses $1 \mathrm{ma-}$ ret 2017.

Studi Dokumentasi, http://www.apb-group.com/studi-dokumentasi/, diakses 21 Maret 2017.

Fauzik (2007) dalam http://repository.usu.ac.id/bitstream/123456789/55003/3/ Chapter\%20II. pdf, diakses 1 maret 2017.

Fauzik. 2007. Chapter II. dalam http://repository.usu. ac.id/bitstream/123456789 /55003/3/ Chapter\%20II.pdf, diakses 1 maret 2017. 
h t t p : / / repository.us u.ac.id/bit stream/123456789/30654/4/Chapter\%20II.pdf, diakes 28 Februari 2017.

Rusman R. Manik, tt, "Pembangunan Sosial di Indonesia: Sebuah Kajian terhadap UU 11 Tahun 2009 tentang Kesejahteraan Sosial dan Teoritis Pembangunan Sosial," https://www.academia. edu/10501825/Pembangunan_Sosial_dan_Kesejahteraan_Sosial_di_Indonesia, diakes 28 Februari $20 \overline{17}$.
Slamet Suprayogi, dkk. tt. "Relevansi Spacial Indeks Kualitas Lingkungan Hidup dengan Pengetahuan Siswa akan Kesiapsiagaan Perubahan Lingkungan dan Iklim," https://publikasiilmiah.ums.ac.id/bitstream/handle/11617/4236/46. pdf? sequence=1, diakses 1 Maret 2016.

World Health Organization (WHO). Environmental Health. Disitasi dari: http://www.WHO.int, diakses 1 maret 2017. 


\section{Lampiran A.}

Hasil Pengolahan Data Persepsi Responden (Variabel X) Provinsi Banten

I. INDIKATOR PENCEMARAN UDARA

1. Saya dapat menghirup udara yang bersih dan segar setiap saat

\begin{tabular}{|c|c|c|c|c|}
\hline A & B & C & D & E \\
\hline Selalu & Sering & Kadang-kadang & Pernah & Tidak pernah \\
\hline $42 \%$ & $30 \%$ & $24 \%$ & $4 \%$ & $0 \%$ \\
\hline
\end{tabular}

2. Polusi udara baik itu baik itu yang bersumber dari pembakaran sampah, kendaraan bermotor maupun industri kerap mengganggu.

\begin{tabular}{|c|c|c|c|c|}
\hline A & B & C & D & E \\
\hline Tidak pernah & Pernah & Kadang-kadang & Sering & Selalu \\
\hline $6 \%$ & $22 \%$ & $26 \%$ & $40 \%$ & $6 \%$ \\
\hline
\end{tabular}

\section{INDIKATOR KUALITAS AIR}

3. Jumlah air bersih yang selama ini digunakan untuk keperluan sehari-hari.

\begin{tabular}{|c|c|c|c|c|}
\hline A & B & C & D & E \\
\hline Sangat memadai & memadai & Cukup memadai & Tidak memadai & Sangat tidak memadai \\
\hline $20 \%$ & $52 \%$ & $22 \%$ & $6 \%$ & $0 \%$ \\
\hline
\end{tabular}

4. Kualitas air bersih yang selama ini digunakan untuk keperluan sehari-hari.

\begin{tabular}{|c|c|c|c|c|}
\hline A & B & C & D & E \\
\hline Sangat memadai & memadai & Cukup memadai & Tidak memadai & Sangat tidak memadai \\
\hline $22 \%$ & $42 \%$ & $30 \%$ & $6 \%$ & $0 \%$ \\
\hline
\end{tabular}

5. Saya menjumpai air sungai dalam kondisi kotor dan tercemar.

\begin{tabular}{|c|c|c|c|c|}
\hline A & B & C & D & E \\
\hline Tidak pernah & Pernah & Kadang-kadang & Sering & Selalu \\
\hline $8 \%$ & $26 \%$ & $20 \%$ & $44 \%$ & $2 \%$ \\
\hline
\end{tabular}

6. Saya mengalami sakit (seperti diare, gatal-gatal, dll) setelah menggunakan air sumur/sungai.

\begin{tabular}{|c|c|c|c|c|}
\hline A & B & C & D & E \\
\hline Tidak pernah & Pernah & Kadang-kadang & Sering & Selalu \\
\hline $34 \%$ & $34 \%$ & $22 \%$ & $8 \%$ & $2 \%$ \\
\hline
\end{tabular}

\section{INDIKATOR TUTUPAN LAHAN}

7. Menurut saya, kondisi hutan yang ada di provinsi ini adalah:

\begin{tabular}{|c|c|c|c|c|}
\hline A & B & C & D & E \\
\hline Sangat baik & Baik & Cukup baik & Tidak baik & Sangat tidak baik \\
\hline $4 \%$ & $28 \%$ & $48 \%$ & $20 \%$ & $0 \%$ \\
\hline
\end{tabular}

8. Kejadian kerusakan hutan seperti penebangan liar, kebakaran, di provinsi ini:

\begin{tabular}{|c|c|c|c|c|}
\hline A & B & C & D & E \\
\hline Tidak pernah & Pernah & Kadang-kadang & Sering & Selalu \\
\hline $12 \%$ & $44 \%$ & $34 \%$ & $8 \%$ & $2 \%$ \\
\hline
\end{tabular}




\section{INDIKATOR KEANEKARAGAMAN HAYATI}

9. Kondisi keberagaman tumbuhan-tumbuhan yang ada di provinsi ini:

\begin{tabular}{|c|c|c|c|c|}
\hline A & B & C & D & E \\
\hline Sangat beragam & Beragam & Cukup beragam & Tidak beragam & Sangat tidak beragam \\
\hline $22 \%$ & $32 \%$ & $36 \%$ & $10 \%$ & $0 \%$ \\
\hline
\end{tabular}

10. Kondisi keberagaman hewan yang ada di provinsi ini:

\begin{tabular}{|c|c|c|c|c|}
\hline A & B & C & D & E \\
\hline Sangat beragam & Beragam & Cukup beragam & Tidak beragam & Sangat tidak baik \\
\hline $20 \%$ & $36 \%$ & $32 \%$ & $10 \%$ & $0 \%$ \\
\hline
\end{tabular}

11. Kejadian kepunahan beberapa jenis tumbuhan di provinsi ini akhir-akhir ini:

\begin{tabular}{|c|c|c|c|c|}
\hline A & B & C & D & E \\
\hline Tidak pernah & Pernah & Kadang-kadang & Sering & Selalu \\
\hline $30 \%$ & $30 \%$ & $34 \%$ & $6 \%$ & $0 \%$ \\
\hline
\end{tabular}

12. Kejadian kepunahan beberapa jenis hewan di provinsi ini akhir-akhir ini:

\begin{tabular}{|c|c|c|c|c|}
\hline A & B & C & D & E \\
\hline Tidak pernah & Pernah & Kadang-kadang & Sering & Selalu \\
\hline $28 \%$ & $24 \%$ & $36 \%$ & $10 \%$ & $0 \%$ \\
\hline
\end{tabular}

\section{INDIKATOR KESEHATAN MASYRAKAT}

13. Secara rata-rata, jumlah penduduk di provinsi ini yang akan tetap sehat dan bugar sampai usia 70 tahun diprakirakan:

\begin{tabular}{|c|c|c|c|c|}
\hline A & B & C & D & E \\
\hline Sangat banyak & Banyak & Cukup banyak & Tidak banyak & Tidak ada \\
\hline $2 \%$ & $20 \%$ & $42 \%$ & $34 \%$ & $0 \%$ \\
\hline
\end{tabular}

14. Jumlah bayi yang meninggal sebelum mencapai usia balita akhir-akhir ini:

\begin{tabular}{|c|c|c|c|c|}
\hline A & B & C & D & E \\
\hline Tidak ada & Tidak banyak & Cukup banyak & Banyak & Sangat banyak \\
\hline $14 \%$ & $50 \%$ & $26 \%$ & $8 \%$ & $2 \%$ \\
\hline
\end{tabular}

15. Kejadian penyakit atau wabah penyakit yang melanda penduduk di provinsi ini akhir-akhir ini:

\begin{tabular}{|c|c|c|c|c|}
\hline A & B & C & D & E \\
\hline Tidak ada & Tidak banyak & Cukup banyak & Banyak & Sangat banyak \\
\hline $20 \%$ & $42 \%$ & $26 \%$ & $12 \%$ & $0 \%$ \\
\hline
\end{tabular}

16. Jumlah anak-anak yang meninggal sebelum mencapai usia remaja akhir-akhir ini:

\begin{tabular}{|c|c|c|c|c|}
\hline A & B & C & D & E \\
\hline Tidak ada & Tidak banyak & Cukup banyak & Banyak & Sangat banyak \\
\hline $6 \%$ & $60 \%$ & $26 \%$ & $8 \%$ & $0 \%$ \\
\hline
\end{tabular}

17. Kasus balita yang kekurangan gizi di provinsi ini akhir-akhir ini:

\begin{tabular}{|c|c|c|c|c|}
\hline A & B & C & D & E \\
\hline Tidak ada & Tidak banyak & Cukup banyak & Banyak & Sangat banyak \\
\hline $10 \%$ & $40 \%$ & $32 \%$ & $14 \%$ & $4 \%$ \\
\hline
\end{tabular}


18. Kasus kasus Ibu yang meninggal saat melahirkan di provinsi ini akhir-akhir ini:

\begin{tabular}{|c|c|c|c|c|}
\hline A & B & C & D & E \\
\hline Tidak ada & Tidak banyak & Cukup banyak & Banyak & Sangat banyak \\
\hline $6 \%$ & $58 \%$ & $26 \%$ & $8 \%$ & $2 \%$ \\
\hline
\end{tabular}

\section{INDIKATOR KESEHATAN LINGKUNGAN}

19. Kemudahan akses terhadap air bersih dari masing-masing rumah tangga selama ini:

\begin{tabular}{|c|c|c|c|c|}
\hline A & B & C & D & E \\
\hline Sangat mudah & Mudah & Cukup mudah & Tidak mudah & Sangat tidak mudah \\
\hline $12 \%$ & $28 \%$ & $42 \%$ & $18 \%$ & $0 \%$ \\
\hline
\end{tabular}

20. Jumlah rumah dengan kondisi sehat dan bersih di provinsi ini:

\begin{tabular}{|c|c|c|c|c|}
\hline A & B & C & D & E \\
\hline Sangat banyak & Banyak & Cukup banyak & Tidak banyak & Tidak ada \\
\hline $4 \%$ & $30 \%$ & $50 \%$ & $16 \%$ & $0 \%$ \\
\hline
\end{tabular}

21. Jumlah rumah yang memiliki sarana MCK bersih di provinsi ini:

\begin{tabular}{|c|c|c|c|c|}
\hline A & B & C & D & E \\
\hline Sangat banyak & Banyak & Cukup banyak & Tidak banyak & Tidak ada \\
\hline $12 \%$ & $30 \%$ & $46 \%$ & $12 \%$ & $0 \%$ \\
\hline
\end{tabular}




\section{E. Pemenuhan Kebutuhan Dasar (Variabel Y) Banten}

Keterangan *)

ST: Sangat terpenuhi T: Terpenuhi CT: Cukup terpenuhi

KT: Kurang terpenuhi TT: Tidak terpenuhi

\begin{tabular}{|c|c|c|c|c|c|c|c|}
\hline No & & Indikator ${ }^{*}$ ) & ST & $\mathrm{T}$ & CT & KT & TT \\
\hline \multirow[t]{4}{*}{1.} & & \multicolumn{6}{|l|}{ Materi } \\
\hline & $\mathrm{A}$ & $\begin{array}{l}\text { Penyediaan makanan bergizi yang dibutuhkan } \\
\text { masyarakat untuk keberlangsungan pola hidup } \\
\text { sehat }\end{array}$ & $18 \%$ & $40 \%$ & $24 \%$ & $16 \%$ & $2 \%$ \\
\hline & $B$ & $\begin{array}{l}\text { Penyediaan busana/pakaian yang layak dan } \\
\text { terjangkau dibutuhkan masyarakat }\end{array}$ & $18 \%$ & $40 \%$ & $28 \%$ & $12 \%$ & $2 \%$ \\
\hline & $\mathrm{C}$ & $\begin{array}{l}\text { Ketersediaan perumahan sebagai tempat tinggal } \\
\text { yang layak }\end{array}$ & $8 \%$ & $32 \%$ & $32 \%$ & $24 \%$ & $4 \%$ \\
\hline \multirow[t]{6}{*}{2.} & & \multicolumn{6}{|l|}{ Fisik } \\
\hline & $\mathrm{A}$ & $\begin{array}{l}\text { Ketersediaan sarana dan prasarana kesehatan } \\
\text { seperti rumah sakit dan Puskesmas }\end{array}$ & $16 \%$ & $40 \%$ & $30 \%$ & $14 \%$ & $0 \%$ \\
\hline & B & $\begin{array}{l}\text { Ketersediaan tenaga kesehatan seperti dokter, } \\
\text { bidan dan perawat }\end{array}$ & $14 \%$ & $38 \%$ & $32 \%$ & $16 \%$ & $0 \%$ \\
\hline & $\mathrm{C}$ & $\begin{array}{l}\text { Ketersediaan lingkungan yang bersih, termasuk } \\
\text { udara bersih, sungai, danau yang tidak tercemar }\end{array}$ & $8 \%$ & $16 \%$ & $40 \%$ & $32 \%$ & $4 \%$ \\
\hline & $\mathrm{D}$ & Kemudahan akses terhadap sumber air bersih & $18 \%$ & $26 \%$ & $32 \%$ & $22 \%$ & $2 \%$ \\
\hline & $\mathrm{E}$ & $\begin{array}{l}\text { Ketersediaan fasilitas dan sarana prasarana untuk } \\
\text { pengelolaan sampah yang baik }\end{array}$ & $6 \%$ & $12 \%$ & $34 \%$ & $42 \%$ & $6 \%$ \\
\hline \multirow[t]{5}{*}{3.} & & \multicolumn{6}{|l|}{ Mental } \\
\hline & $\mathrm{A}$ & $\begin{array}{l}\text { Perasaan aman dari berbagai jenis kejahatan, } \\
\text { gangguan, kriminalisasi, dsb. }\end{array}$ & $6 \%$ & $16 \%$ & $36 \%$ & $38 \%$ & $4 \%$ \\
\hline & B & $\begin{array}{l}\text { Kesempatan untuk mendapatkan pendidikan yang } \\
\text { berkualitas mulai pada tingkat dasar dan } \\
\text { menengah (SD, SMP, SLTA) }\end{array}$ & $6 \%$ & $32 \%$ & $50 \%$ & $10 \%$ & $2 \%$ \\
\hline & $\mathrm{C}$ & $\begin{array}{l}\text { Pendidikan yang berkualitas mulai pada tingkat } \\
\text { lanjut (misal perguruan tinggi) }\end{array}$ & $10 \%$ & $20 \%$ & $38 \%$ & $30 \%$ & $2 \%$ \\
\hline & $\mathrm{D}$ & $\begin{array}{l}\text { Perasaan bahagia dan bergembira dalam } \\
\text { menjalani kehidupan }\end{array}$ & $20 \%$ & $28 \%$ & $44 \%$ & $8 \%$ & $0 \%$ \\
\hline \multirow[t]{4}{*}{4.} & & \multicolumn{6}{|l|}{ Spiritual } \\
\hline & A & $\begin{array}{l}\text { Kebebasan untuk melaksanakan ibadah menurut } \\
\text { agama dan kepercayaannya }\end{array}$ & $58 \%$ & $24 \%$ & $16 \%$ & $2 \%$ & $0 \%$ \\
\hline & B & $\begin{array}{l}\text { Kesempatan untuk mengaktualisasika diri dan } \\
\text { berkembang sesuai dengan potensinya }\end{array}$ & $24 \%$ & $40 \%$ & $30 \%$ & $4 \%$ & $2 \%$ \\
\hline & $\mathrm{C}$ & $\begin{array}{l}\text { Kesempatan untuk dapat melakukan kehidupan } \\
\text { sosial dalam pergaulan masyarakat secara rukun, } \\
\text { sejajar dan saling menghargai. }\end{array}$ & $22 \%$ & $48 \%$ & $24 \%$ & $6 \%$ & $0 \%$ \\
\hline
\end{tabular}

